\title{
ARTYKUŁY
}

http://dx.doi.org/10.15762/ZH.2018.23

KATARZYNA PĘKACKA-FALKOWSKA

(Uniwersytet Medyczny im. Karola Marcinkowskiego w Poznaniu)

\section{HORTI SICCI JACOBA BREYNE'A Z 1659 I 1673 ROKU}

Słowa kluczowe: Prusy Królewskie - XVIIw., historia botaniki, herbaria historyczne - XVII w., herbarium vivum, etnobotanika

W 1714 r. w jednym z listów pisanych do Johanna Philippa Breyne’a lekarz nadworny króla Augusta II Mocnego Christian Heinrich Erndtel skarżył się, że Polacy interesują się tylko sprawami politycznymi i wojnami, nie zaś studiami nad roślinami ${ }^{1}$. Erndtel, tak jak jego korespondent, był doktorem medycyny i filozofii oraz zapalonym botanikiem, który rozpoczął w nowej ojczyźnie badania nad polską florą rodzimą ${ }^{2}$. Ich zwieńczeniem miała stać się publikacja Viridarium vel Catalogus plantarum circa Warsaviam nascentum ${ }^{3}$.

Utyskiwania Erndtela na stan wiedzy botanicznej w Rzeczypospolitej Obojga Narodów na progu XVIII w. były zasadne. Z wyjątkiem katalogów roślin rosnących $\mathrm{w}$ warszawskich ogrodach królewskich ${ }^{4}$ oraz pojedynczych ob-

* Materiały $z$ Forschungsbibliothek Gotha pozyskano w ramach Herzog-Ernst-Stipendium der Fritz Thyssen Stiftung.

${ }^{1}$ Forschungsbibliothek (dalej cyt. FB) Gotha, Chart. B. 786, k. 167-168v.

${ }^{2}$ Więcej o pobycie Erndtela w Polsce i jego zainteresowaniach botanicznych w drugiej dekadzie XVIII w. zob. Katarzyna P̨̨Kacka-Falkowska, Wstęp, [in:] Christian Heinrich ERndTEL, Pamiętnik podroży uczonej do Anglii i Holandii (1706-1707), tłum. i oprac. Katarzyna P巨̨KACKa-FalKowsKa, Halina Bogusz, Warszawa 2018, s. 11-36.

${ }^{3}$ Christian Heinrich Erndtel, Viridarium, Warsaviense sive Catalogus Plantarum Circa Warsaviam Crescentium, [in:] idem, Warsavia Physice Illustrata, Sive De Aere, Aquis, Locis Et Incolis Warsaviae, Eorundemque Moribus Et Morbis Tractatus; Cui Annexum Est Viridarium, Vel Catalogus Plantarum Circa Warsaviam Nascentium, Dresdae 1730, s. 1-132.

${ }^{4}$ Catalogi plantarum quae A. 1651 Varsaviae in hortis botanicis regis Ioannis Casimiri colebantur, secundum conspectus hortulanorum Bartholomei Gei et Jacobi Haic: accedit catalogus tertius plantarum indigenarum, quae circa Varsaviam nascuntur; Królewskie ogrody botaniczne króla Jana Kazimierza $w$ Warszawie oraz systematyczny spis roślin tamże hodowanych, oprac. Józef Rostafiński, Kraków 1928; Alina Doroszewska, Królewskie ogrody botaniczne w Warszawie za Jana Kazimierza, Kwartalnik Historii Nauki i Techniki (dalej cyt. KHNT), R. 31: 1986, nr 2, s. 397-410; eadem, The oldest botanical garden in Warsaw, [in:] Studies on the history of Bota- 
serwacji lekarzy i chirurgów nadwornych opublikowanych na łamach czasopisma „Miscellanea Curiosa” ${ }^{2}$, w XVII w. i pierwszym dwudziestoleciu wieku XVIII na ziemiach polskich nie powstawały w zasadzie żadne prace botanicz$\mathrm{ne}^{6}$. Informował o tym z żalem także J. P. Breyne, kiedy opisywał stan badań z zakresu historii naturalnej prowadzonych w Koronie ${ }^{7}$. Chlubny wyjątek na mapie Rzeczypospolitej polsko-litewskiej stanowiły jedynie Prusy Królewskie. Wielkie miasta tej prowincji z Gdańskiem na czele były ważnymi ośrodkami studiów z zakresu historia naturalis, m.in. botaniki, mineralogii, zoologii i medycyny. W Gdańsku od XVI stulecia działali bowiem uczeni (Gelehrte) oraz amatorzy (Liebhaber) zainteresowani florą rodzimą i obcą w wymiarze nie tylko estetycznym, komercyjnym czy praktycznym ${ }^{8}$, lecz także - w przypadku części z nich - czysto poznawczym.

Zainteresowaniom botanicznym dawnych gdańszczan poświęcono wiele prac i artykułów. Skupiały się one m.in. na ich fascynacji plantae exoticae, pasjach kolekcjonerskich i bibliofilskich oraz, co istotne, autochorologii ${ }^{9}$. Trzeba bowiem pamiętać, że badania nad roślinami autochtonicznymi miały w Pru-

nical Gardens and Arboreta in Poland, red. Alicja Zemanek, Bogdan Zemanek, Kraków 1993, s. $47-58$.

${ }^{5}$ Zob. np. niekompletną listę tytułów w: Marcin Łyskanowski, Polonica w czasopiśmie XVII i XVIII wieku „Miscellanea Curiosa”, Historia nauk biologicznych i medycznych, z. 5: 1961, s. $55-62$.

${ }^{6} \mathrm{O}$ botanice jako samodzielnej nauce można mówić od czasów Andrei Cesalpino i Caspara Bauhina, którzy nie zwracając w swych dziełach uwagi na użytkowość roślin, uwolnili botanikę z roli dyscypliny pomocniczej medycyny. Stąd studia botaniczne to takie, które zajmują się roślinami jako samodzielnymi bytami. Być może pracą stricte botaniczną był zaginiony druk Gabriela Joannicego Plantarum Cracoviensium indicem proprium latine confectum Serenissimae Principi Dominae Annae Infanti Sueciae oblatum wydany w Krakowie w $1616 \mathrm{r}$.

${ }^{7}$ Johann Philipp Breyne, Praefatio ad Lectorem benevolum, [in:] Georgii Andreae HeLWING, cum praefatione Johannis Philippi BreyniI, in qua de scriptoribus rerum naturalium Borussiae \& Poloniae agitur, \& multi errores Florae Prussicae modeste corriguntur, Flora quasimodogenita, sive enumeratio aliquot plantarum indigenarum in Prussia, quarum in herbariis hectenus editis Borussicis aut nulla, aut superficiaria facta est mentio, additis nonnullis iconibus descriptionibus et observationibus nec non annexo florilegio ad clima Prussiae accommodato, in gratiam botanophilorum adornata, Gedani 1712, s. 1-2. Breyne nie zaliczał do związanych z Rzecząpospolitą Obojga Narodów badaczy historia naturlis Jana Jonstona.

${ }^{8} \mathrm{~W}$ wymiarze użytkowym tudzież praktycznym roślinami interesowali się gdańscy lekarze i aptekarze, np. J. Placotomius; w wymiarze komercyjnym - liczni kupcy, m.in. ojciec J. Breyne’a; natomiast $\mathrm{w}$ wymiarze estetycznym - m.in. tacy kolekcjonerzy bez inklinacji botanicznych, jak Ch. Gottwald (który posiadał w swoim domu m.in. kwitnące erytryny).

${ }^{9}$ Zob. np. Urszula Szy bкоwsкa, Magdalena Madeja-Grzyb, Herbaria i florilegia od XV do XVIII wieku ze zbiorów PAN Biblioteki Gdańskiej, Pruszcz Gdański 2017; Magdalena ZiarneK, Badacze szaty roślinnej Pomorza sprzed 1945 roku, Szczecin 2012, s. 15-30; Karolina TARgosz, Jacob Breynius 1637-1697, „botanicus celeberrimus” w wymiarze europejskim, Kraków 2010; Tadeusz Sulma, Zofia Schwarz, Z dziejów botaniki na Pomorzu Gdańskim. Cz. II: Rozwój botaniki w Gdańsku w dobie Oświecenia, Studia i Materiały z Dziejów Nauki Polskiej, Seria B., z. 27: 1977, 
sach Królewskich długą tradycję, stąd szata roślinna żadnej innej prowincji I Rzeczypospolitej nie została omówiona równie wnikliwie.

Pod koniec XVIw. o szacie roślinnej okolic Gdańska pisał Johann Wigand $^{10}$. W XVII w. wśród uczonych podejmujących badania botaniczne nad florą rodzimą wymienić należy Nicolausa Oelhafa ${ }^{11}$, Johanna Loesela ${ }^{12}$, Christiana Menzela ${ }^{13}$, Lorentza Eichstada ${ }^{14}$ i Jacoba Breyne’a. Stulecie później badaniami nad plantae indigenae Prus Królewskich wsławił się natomiast Gottfried Reyger $^{15}$. W pierwszej połowie XVIII w. zainteresowania florystyczne wykazywali, co oczywiste, również inni gdańscy Gelehrte, m.in. J. P. Breyne czy Jacob Theodor Klein, acz w znacznie większym stopniu niż na roślinach lokalnych koncentrowali się oni na plantae exoticae i ich aklimatyzacji w Gdańsku ${ }^{16}$.

s. 63-118; iidem, Z dziejów botaniki na Pomorzu Gdańskim, ibid., z. 14: 1968, s. 25-74. W wymienionych pracach została zebrana podstawowa literatura przedmiotu.

${ }^{10}$ Johann Wigand, Catalogvs herbarvm in Borvssia nascentium, [in:] Vera historia de succino Borussico, de alce Borussica, \& de herbis in Borussia nascentibus. Item, de sale creatura Dei saluberrima, consideratio methodica, \& theologica, etc., Jenae 1590, s. 48-88.

${ }^{11}$ Nicolaus Oelhafius, Elenchus plantarum circa nobile Borusforum Dantiscum suâ sponte nascentium: Earundem Synonyma Latina \& Germanica, loca natalitia, florum tempora \& vires exhibens, Stettini 1643 (Gedanii 1656); Hugo Wilhelm Conwentz, Oelhafens Elenchus plantarum circa Dantiscum nascentium, Schriften der Naturforschenden Gesellschaft Danzig NF, Bd. 4: 1877, H. 2, s. 1-33.

${ }^{12}$ Ioanni Loeseli plante in Borussia sponte nascentes, Regiomonti 1654; idem, Flora Prussica; sive, Plantae in regno Prussiae sponte nascentes. Quarum catalogum \& nomina Johannes Loeselius [...] olim disseruit, nunc additis nitidissimis iconibus rariorum partim ab aliis nondum delineatarum plerarumque Prussiae propriarum \& inquilinarum plantarum, earundemque accurata descriptione, nec non adjectis synonymiis veterum botanicorum, interspersisque observationibus historico-philologico-criticis \& medio-practicis noviter efflorescentes curante Johanne Gottsched, Regiomonti 1703.

${ }^{13}$ Christian Mentzel, Centuria plantarum circa nobile Gedanum sponte nascentium adjecta appendicis loco ad Elenchum plantarum gedanensium excell. \& exper. Dn Nicolai Oelhafii, regi medici, et physici gedanensis, Dantisci 1650; idem, Catalogus plantarum circa Gedanum sponte nascendium, Dantisci 1658.

${ }^{14}$ Elenchus plantarum, circa nobile Borussorum Dantiscum, sua sponte nascentium D. Nicolai Oelhafi etc. cum synonymia earundem latina et germanica, indice autorum, locis natalibus, florum temporibus et viribus, denuo recensitus ac locupletatus a successore eius, (Laurentió Eichstadio) de quo in praefatione, Gedani 1656.

${ }^{15}$ Gottfried Reyger Soc. Phys. Ged. Secretarii, Tentamen Florae Gedanensis Methodo Sexuali Adcommodatae, Gedanii 1764, https://doi.org/10.5962/bhl.title.45250.

${ }^{16}$ Zob. np. Biblioteka Gd. PAN, Ms 534, k. 130-143; Zofia Szwarc, Prywatne ogrody botaniczne a rozwój nauk przyrodniczych w ośrodku gdańskim w XVI-XVIII w., KHNT, t. 31: 1986, nr 2, s. 411-444; T. Sulma, Z. Schwarz, Z dziejów botaniki na Pomorzu Gdańskim. Cz. II, passim; M. Ziarnek, Badacze, s. 25-30; Katarzyna Pॄ̨каска-Falkowska, Johann Philipp Breyne i jego ogrody: hortus vivus i hortus siccus, [in:] Natura Homines. Studia z historii środowiskowej, vol. 1: Historia - klimat - przyroda. Perspektywa antropocentryczna, red. Piotr Oliński, Wojciech PIASEK, Torun 2018 [w druku]. Johann Philipp Breyne otrzymywał liczne informacje o florze rodzimej Korony od Ch. H. Erndtela, sam zaś dzielił się swoją wiedzą m.in. z Helwingiem 
Roślinami autochtonicznymi Pomorza interesowali się także mieszkańcy innych części Europy ${ }^{17}$, w szczególności sąsiadujących z Prusami Królewskimi Prus Książęcych. Wśród nich znaleźli się utrzymujący bliskie kontakty z gdańszczanami, głównie J. P. Breynem, Georg Andreas Helwing ${ }^{18}$ i Matthias Ernst Boretius ${ }^{19}$. W zachowanej w zbiorach polskich spuściźnie obu uczonych - teścia i zięcia - znajduje się kilka spośród ich herbaria viva ${ }^{20}$, tj. zielników sporządzonych $\mathrm{z}$ zasuszonych roślin ${ }^{21}$. Herbaria te $\mathrm{w}$ polskiej literaturze botanicznej uważa się za najstarsze zachowane horti sicci z terenów dzisiejszej Polski ${ }^{22}$. W zbiorach Naturalis Biodiversity Centre / Nationaal Herbarium Nederland w Lejdzie przechowywane są jednak dwie starsze kolekcje tego typu.

i uczonymi angielskimi. Por. K. PęKacka-Falkowska, Wstęp, passim; M. Georgii Andreae HelwiNGII, pastor. Angerburg. [...], Florae campana seu pulsatilla cum suis speciebus et varietatibus methodice considerata et inter spersis variis observationibus oculis curiosorum exposita, cum XII iconibus, qvarum nonnullae nunqvam ante hac aeri incisae. [wariant tytułu:] Florae campana seu pulsatilla cum suis speciebus et varietatibus methodice considerata, Lipsiae 1719, s. 65.

${ }^{17}$ Alix Cooper, Inventing the Indigenous: Local Knowledge and Natural History in Early Modern Europe, Cambridge 2007, passim; K. PЕ̨KACKA-FALKOwsKa, Johann Philipp Breyne i jego ogrody.

${ }^{18}$ Flora quasimodogenita: Sive enumeratio aliquot plantarum indigenarum in Prussia, Quarum in Herbariis hactenus editis borussicis aut nulla, aut superficiaria facta est mentio, additis nonnullis iconibus, descriptionibus et observationibus, nec non annexo florilegio, ad clima Prussiae accomodato. Cum praefatione Johannis Philippi Breynii, Gedani 1712; idem, Supplementum florae Prussicae: seu enumeratio plantarum indigenarum post editam Floram quasimodogenitam additis synonymiis, appellationibus Latino-Germanico-Polonicis, nec non observationibus quibusdam curiosis, ultra numerum quadringentesimum aucta, Gedanii 1726.

${ }^{19}$ Stanisław FlIs, Maciej Ernest Borecki (Boretius) - Znany lekarz mazurski XVIII wieku, Polski Tygodnik Lekarski, 1956, nr 38, s. 1637-1638; idem, Panegiryk z pierwszej połowy XVIII wieku ku uczczeniu pamięci Macieja Ernesta Boretiusa (Boreckiego), Komunikaty Mazursko-Warmińskie, 1964, nr 4, s. 514-519.

${ }^{20}$ Dzieło Boretiusa, ucznia Helwinga, zdygitalizowane fragmenty zielnika Boretiusa: http:// www.zielnik.biol.uw.edu.pl/?page_id=2941; zdygitalizowany zielnik Helwinga: Herbarium vivum plantarum sponte in Prussia nascentum, vol. I-III: https://polona.pl/search/?filters=creator: \%22Helwing,_Georg_Andreas_(1666--1748)\%22 (dostęp z 19 IX 2018 r.).

${ }^{21} \mathrm{O}$ tradycji sporządzania horti sicci i ich znaczeniu dla rozwoju botaniki w epoce wczesnonowożytnej zob. np. Brian W. OgLIVIE, The Science of Describing: Natural history in Renaissance Europe, Chicago-London 2008, s. 165-174.

${ }^{22} \mathrm{O}$ herbariach Helwinga zob. Krzysztof Spalik, Pre-Linnaean herbaria viva of Helwing in the collections of the National. Library of Poland and the University of Warsaw, Acta Societati Botanicorum Poloniae, vol. 83: 2014, no. 1, s. 13-16, DOI: https://doi.org/10.5586/asbp.2014.008. Zgodnie z opinią Alicji Zemanek najstarszym hortus siccus z ziem Rzeczypospolitej Obojga Narodów mogło być zaginione herbarium Anny Wazówny, natomiast „najstarsza [przechowywana] w Polsce [współcześnie] kolekcja roślin o charakterze naukowym, to herbarium włoskiego przyrodnika, Sylwiusza Boccone z 1674 r., zachowane w Zielniku Instytutu Botanicznego Uniwersytetu Wrocławskiego", zob. eadem, Odnalezienie prawdopodobnych śladów pierwszego polskiego zielnika królewny Anny Wazówny, KHNT, t. 41: 1996, nr 3-4, s. 203. Zielnik ten obejmuje rośliny śródziemnomorskie. 
Są to zielniki obejmujące rośliny Pomorza Gdańskiego, Kaszub i okolic Torunia, które sporządził w drugiej połowie XVII w. w Gdańsku „Grand Amateur des Fleurs" ${ }^{23}$ Jacob Breyne.

Jacob Breyne jest postacią dobrze rozpoznaną w historiografii polskiej i zagranicznej. Prace mu poświęcone przygotowywali historycy, bibliotekoznawcy, botanicy i uczeni innych specjalności ${ }^{24}$. Na marginesie ich rozważań pozostawał jednak opracowany zaledwie pobieżnie wątek zainteresowania Breyne’a Sr. florą rodzimą Prus Królewskich. Działo się tak dlatego, że badacze polscy i niemieccy czerpali informacje na ten temat z prac drukowanych obu Breyneów, ewentualnie z wybranych elementów spuścizny rękopiśmiennej Breyne’a Jr. ${ }^{25}$ Zachowane Breynowskie horti sicci rozpoznali wyłącznie uczeni holenderscy, acz zostały one odnotowane również przez Brytyjczyków ${ }^{26}$.

${ }^{23}$ FB Gotha, Chart. A 790, k. 126.

${ }^{24}$ Zob. np. Danuta Natalia ZasŁawska, The Floral Still Lifes of Andreas Stech, Acta Historiae Artium Balticae, vol. 1: 2005, s. 101-137; K. TARGOsZ, op.cit. [tu przegląd literatury przedmiotu do roku 2012]; Alicja KurкowA, Jakub i Jan Filip Breynowie: studium z dziejów kultury książki XVII i XVIII wieku, Wrocław-Warszawa-Gdańsk 1989; ead., Jakub i Jan Filip Breynowie uczeni gdańscy XVII i XVIII w., KHNT, t. 37: 1987, nr 3-4, s. 661-678; T. Sulma, Z. SCHWARZ, $Z$ dziejów botaniki na Pomorzu Gdańskim. Cz. II [tu przegląd literatury przedmiotu polskiej, niemieckiej i łacińskiej do lat siedemdziesiątych XX w.].

${ }^{25}$ Zob. polskojęzyczna literatura przedmiotu wymieniona wcześniej oraz Johann Gottlieb BUјACK, Über preußische Naturforscher des 16ten, 17ten und 18ten Jahrhunderts. Biographisch-literarische Skizzen. (Die Danziger Jacob Breyn, Johann Philipp Breyn und Jacob Theodor Klein), Preußische Provinzial-Blätter, Bd. 23: 1840, s. 193-209, 344-359; Hugo Conwentz, WestpreuBische Botaniker der Vergangenheit, Berichte der Deutschen Botanischen Gesellschaft, Bd. 29: 1911, s. 6-15; Hugo von KLINGgRäFf, Zur Geschichte der Botanik in Preussen, Der neuen Preuß. Prov.-Blätter, Bd. 5: 1854, s. 53-63.

${ }^{26}$ Philip Christiaan Molhuysen, Bronnen tot de geschiedenis der Leidsche universiteit 1574-1811, Deel 5: 1725-1765, Bronnen tot de geschiedenis der Leidsche Universiteit. Vijfde deel: 10 Febr. 1725 - 8 Febr. 1765, Gravenhage 1921, s. 87-89; Bibliotheca Academiae Lugduno-Batavae. Catalogus deel XIV. Inventaris van de Handschriften. Eerste Afdeeling, Leiden 1932, s. 150; Simon Jan van Ooststroom, Een 17 de eeuwsch herbarium uit de omgeving van Danzig, [in:] Gedenkboek J. Valckenier Suringar, 24 December 1864-17 October 1932, Wageningen 1942, s. 208-217; Gerard Thissse, Gedroogle schatten, [in:] Bloeiende kennis: Groene ontdekkingen in de Gouden Eeuw, Hilversum 2012, s. 49-50; idem, „Hieronymus van Beverningk (1614-1690), diplomat and plant lover. His garden and herbaria, in particular those of Paolo Boccone (1633-1704), Jacob Breyne (1637-1697) and Paul Hermann (1646-1695)" [maszynopis]; Alette Fleischer, Gardening Nature, Gardening Knowledge: the Parallel Activities of Stabilizing Knowledge and Gardens in the Early Modern Period, [in:] Gardens, Knowledge and the Sciences in the Early Modern Period, ed. Hubertus Fischer, Volker R. Remmert, Joachim Wolschke-Bulmahn, Basel 2016, s. 294-296; eadem, Rooted in fertile soil: seventeenth-century Dutch gardens and the hybrid history of material and knowledge production, proefschrift, Twente 2010, s. 112-116 [mps rozprawy doktorskiej - DOI 10.3990.1.9789036530972]; Frans Antonie STAFLEU, Richard S. COWAN BOHN, Taxonomic literature: a selective guide to botanical publications and collections with dates, commentaries and types, vol. 1, Utrecht 1976, s. 48-50. 
Prace drukowane Breyne’a Sr., w których napomykał o roślinach autochtonicznych okolic Gdańska, to jego Centuria i Prodomus (I) oraz sprawozdania z czasopisma „Miscellanea Curiosa”. I tak, w Setnicy J. Breyne zaznaczał, że interesują go rośliny egzotyczne i autochtoniczne, acz to te ostatnie, jak podkreślał, ukochał najszczerzej ${ }^{27}$. W Centurii wymieniał jednak tylko dziesięć plantae indigenae Prus Królewskich i Korony ${ }^{28}$, określając je jako rzadko występujące „pod naszym niebem”29. Pozostałe to rośliny egzotyczne, które albo podziwiał w ogrodach Holandii, albo otrzymał zasuszone od swoich przyjaciól. Pięć informacji o roślinach kaszubskich - także tych przesłanych przez Breyne’a do Lejdy w celu aklimatyzacji - pojawiało się w Prodomus (I) ${ }^{30}$. Również w „Miscellaneach” zaledwie pięć spośród nadesłanych przezeń 26 case studies odnosiło się do flory rodzimej Prus Królewskich i Korony ${ }^{31}$.

Wiadomo przy tym, że J. Breyne planował publikację samodzielnej pracy poświęcanej roślinom autochtonicznym Pomorza i Kaszub ${ }^{32}$. Roboczy tytuł opracowywanego przez wiele lat dzieła - tractatus [...] de plantis in Borusia Occidentali et Cassubia ${ }^{33}$, Viridarius [...] Borusiacus ${ }^{34}$ i Viridarius Prussiae occidentalis ataque Cassubiae ${ }^{35}$ - Breyne Sr. przytaczał wielokrotnie w swoich pracach drukowanych oraz rękopisach. Wspominał o nim także w listach do

${ }^{27}$ Jacobi BreyniI, Ad lectorem botanicum Praefatio, [in:] Centuria (1678), b.s. Także Benjamin Engelke w Ad Jacobum Breynium amicum, rei herbariae peritissimum. Elegia opublikowanej w Centurii (1678) wskazywał na różnorodność ciekawych roślin rosnących na Kaszubach.

${ }^{28}$ J. Breynil, Centuria (1678), s. 102, 104-107, 130-135, 145, 162, 183-184. Por. H. W. CoNWENTZ, op.cit., s. 28.

${ }^{29}$ Ad lectorem Botanicum Praefatio, [in:] J. Breynil, Centuria (1678), b.s.

${ }^{30}$ Jacobi BreYnII, Prodromus fasciculi rariorum plantarum, Anno M.DC.LXXIX. in hortis Celeberrimis Hollandiae, praefertim Incomparabili \& Nobilissimo illo Florae Pandocheo Illustrissimi atqve Excellentissimi Domini, Domini Hieronymi van Beverningk etc. observatarum a Jacobo Breynio, Gedanensi. Cui accedunt Interrogationes de nonnullis Plantarum ab Auctore in Centuria prima descriptarum partibus, quibus, tempore editionis Centuriae primae, Idem ille ut plurimum destitutus fuit, Gedani 1680 (dalej cyt. Prodomus I), s. 29, 40, 42, 45, 52.

${ }^{31}$ M. Łyskanowski, op.cit., s. 58, 60; K. TArgosz, op.cit., s. 32-35; Obs. CCLXXXXIXCCXC, s. 509-511 (Miscellanea Curiosa, An. 3: 1672); Obs. CIX, s. 138; Obs. XXXV, CXLIX, s. 144, 192 (Miscellanea Curiosa, An. 4/5: 1673). Być może w jakimś stopniu także Obs. CLI (Miscellanea Curiosa, An. 4/5: 1673), s. 194-195, dotyczyła flory Korony.

32 Zob. np. Z. Schwarz, Prywatne ogrody, s. 419, 422.

${ }^{33}$ Obs. CCLXXXIX. Dn. Jacobi Breynii. De Musco Pulmonario terrestri sanguineo, Miscellanea Curiosa, An. 3: 1672, s. 510; FB Gotha, Chart. A790, k. 24.

${ }^{34}$ Jacobi Breynii Gedanensis Icones Exoticarum aliarumque Minus Cognitarum Plantarum in Centuria Prima descriptaru, Gedani 1678, s. 102, 131.

${ }^{35}$ J. Breynit, Prodomus I, s. 52; A. Fleischer, Gardening Nature, s. 296; The Sloane herbarium: an annotated list of the Horti sicci composing it; with biographical details of the principal contributors, based on records compiled by the late James BRITTEN; with an introd. by Spencer SAVAGE; rev. and edited by James Edgar DANDY, London 1958, s. 97, https://doi.org/10.5962/bhl. title.137366. 
swoich przyjaciół ${ }^{36}$. Również jego syn Johann Philipp zaświadczał, że ojciec planował wydanie Pomerelliae Viridarius, bogato ilustrowanej książki z opisami rzadkich roślin rosnących dziko w Prusach Królewskich ${ }^{37}$. Pracę nad publikacją w wyniku śmierci Breyne’a Sr. przejął po powrocie z peregrinatio medica Breyne Jr., niemniej z bliżej nieokreślonych powodów, być może braku zainteresowania kontynuacją dzieła ojca, nigdy jej nie skończył. Utyskiwał nad tym G. Reyger ${ }^{38}$, który przygotowując Tentamen florae Gedanensis methodo sexuali adcommodatae, chętnie korzystał $\mathrm{z}$ materiałów botanicznych pozostawionych przez obu Breyne’ów ${ }^{39}$.

Jak się wydaje, flora lokalna Prus Królewskich i Korony budziła zainteresowanie Breyne’a Sr. już od jego lat młodzieńczych ${ }^{40}$. Świadczyć o tym mogą m.in. wypowiedzi jego nauczyciela Ch. Menzela czy fragmenty jego biografii sporządzonej przez Georga Daniela Seylera na podstawie informacji uzyskanych od Breyne’a Jr. ${ }^{41}$ Christian Mentzel nazywał J. Breyne’a „discipulus [...] meus in re Herbaria” 42 oraz podkreślał, że "monstravit quondam quascunque fideliter Herbas, et vidi ingenii Maxima signa tui; sed nunc Discipulus vincis superasque Magistrum pandis \& ingenii munera rara Tui" ${ }^{3}$. Natomiast Seyler pisał, że to właśnie Mentzel jako pierwszy uczył J. Breyne’a res herbaria, któ-

${ }^{36}$ British Library, Sloane, Ms 4066, k. 271: "I am now fully resolved to publish my Viridarium of Prussia \& Cassubia, as soon as ever I [...] take a journey one summer more through Prussia \& Cassubia to take a view and reckonize those plants which I had determined to have this year and had made some beginning too with with [sic] wonderfull success as to the observations tho' my health was not answerable to succeed for it...”. Cyt. za A. Fleischer, Gardening Nature, s. 296. Por. A. Cooper, op.cit., s. 114-115.

${ }^{37}$ J. P. Breyne, Praefatio ad Lectorem benevolum, s. 7; Georg Daniel Seyler, Vita Jacobi Breyni (1736), [in:] Jacob BREYNE, Icones rariorum plantorum \& exoticarum plantarum, Gedani 1739 , s. 7.

${ }^{38}$ G. Reyger, op.cit., s. 5.

${ }^{39}$ Ibid., passim.

${ }^{40}$ Jacob Breyne interesował się m.in. zielnikiem Syreniusza, którego fragmenty miał przepisane i który chwalił w liście z 30 VI 1682 r. adresowanym do króla Jana III Sobieskiego (FB Gotha, Chart. A790, k. 14).

${ }^{41}$ Vita Jacobi Breynii, botanici celeberrimi conscripta a Georgio Daniele Seylero, Gymnasii. Elbingensis nunc rectore dignissimo, [in:] Jacobi Breynii, Gedanensis, Prodromi fasciculi rariorum plantarum: primus et secundus, quondam separatim, nunc nova hac editione multum desiderata coniunctim editi notulisque illustrati / adiectis nominibus et succinctis descriptionibus. Quibus praemittuntur vita et effigies auctoris, cura et studio Joannis Philippi BreYNII, Gedani 1739, s. 5-6; korespondencja w tej sprawie zachowała się w FB Gotha.

${ }^{42}$ Christian Mentzel, Elenchus Auctorum, [in:] idem, Pinax botanonymos polyglottos katholikos, Index nominum plantarum universalis etc., Berolini 1682. Za: K. TARgosz op. cit., s. 29.

${ }^{43}$ Carmina a viris qvibusdam clarissimis In laudem Jacobi Breynii, diversis temporibus composita. Ad Clarissimum Celeberimumque Dn. Jacobum Breynium, Fasciculum Rariorum Plantarum edentem, [in:] Jacobi Breynii, Gedanensis, Prodromi (1739), s. 8. 
rą „diligenti institutione sonit \& adauxit”44. Breyne Sr. z kolei zaświadczał, że w 1650 r. brał udział w wycieczkach botanicznych prowadzonych przez autora Centuria plantarum, „qui prima mihi ostendit fundamenta” wiedzy botanicznej. Być może jako dziecko uczestniczył także w herbationes organizowanych w miesiącach letnich przez doktora filozofii i medycyny Lorentza Eichstadta dla uczniów Gdańskiego Gimnazjum ${ }^{45}$ (wiele lat później Breyne Sr. skądinąd sam organizował analogiczne excursiones botanicas dla swego syna Johanna Philippa ${ }^{46}$ ). Jako młodzieniec prowadził także samodzielne obserwacje roślin kaszubskich ${ }^{47}$. Kierowało nim wtedy pożądanie wiedzy o florze rodzimej: „Amor hic tantum suit \& Ardor, ut'nullis sere nec periculis, nec laboribus, ab inquisitione Plantarum per culta, per inculta et aspera, se deterreri passus sit" ${ }^{\text {" }}$. Wreszcie w swoim ogrodzie uprawiał różne pruskie rośliny lokalne, m.in. szalej jadowity opisywany przez Andreasa Cnoeffela, o czym chętnie informował swych korespondentów ${ }^{49}$.

Tak czy inaczej, jedną z podstaw do opracowania planowanej przez J. Breyne’a książki o roślinach autochtonicznych Prus Królewskich, w szczególności zaś przygotowania rycin, które w drukach botanicznych miały znaczenie fundamentalne, musiały być obok obserwacji roślin żywych także studia nad egzemplarzami zasuszonymi. Exsiccatae w czasach wczesnonowożytnych służyły bowiem nie tylko jako obiekty kolekcjonerskie ${ }^{50}$, lecz także były ważnym materiałem do prowadzenia badań ${ }^{51} \mathrm{z}$ zakresu res herbaria (jako obiekty epistemiczne), działalności edukacyjnej (jako obiekty demonstracyjne) czy wykonywania prac artystycznych (jako nieruchome modele). Ich nieocenioną rolę $\mathrm{w}$ pracy uczonych podkreślał m.in. Andriaan van de Spiegel w Isagoge In rem herbarium, kiedy opisywał metodykę sporządzania hortos hiemales ${ }^{52}$, oraz Caspar Bauhin w Phytopinax i Pinax ${ }^{53}$.

${ }^{44}$ Vita Jacobi Breynii, s. 6.

${ }^{45}$ Gdańskie Gimnazjum Akademickie, t. 2: Wybór źródeł z XVI i XVII wieku, red. Lech MoKRZECKI, Gdańsk 2008, s. 209, 263-264; K. TARGosz, op.cit., s. 17-18; Lorenz EICHSTAEDT, Johann MöLler, Exercitatio phytologica de plantis in genere, Gedani 1648, par. 72-76.

${ }^{46}$ FB Gotha, Chart. A788, k. 47-48.

${ }^{47}$ J. Breyni, Centuria, s. 105.

${ }^{48}$ Vita Jacobi Breynii, s. 6, przyp. F.

${ }^{49}$ FB Gotha, Chart. A790, k. 2, 56-56v; informacje dotyczące wpisu Andreasa Cnoeffela, De nassa vel corbi Piscatora naturali, Miscellanea Curiosa, An. 3: 1672, s. 436-437.

${ }^{50} \mathrm{~W}$ swoich kolekcjach i bibliotekach mieli je m.in. Ch. H. Erndtel i J. T. Klein.

${ }^{51}$ W szczególności późną jesienią, zimą oraz wczesną wiosną.

${ }^{52}$ Adriani Spigelii Bruxellensis Philosophi Ac Medici Patavini Isagoges In Rem Herbariam Libri Duo: Cum Indice Rerum Capitum. Editio prioribus correctior, Helmestadii 1667, s. 172.

${ }^{53}$ Davina Benkert, The "Hortus Siccus" as a Focal Point: Knowledge, Environment, and Image in Felix Platter's and Caspar Bauhin's Herbaria, [in:] Sites of Mediation: Connected Histories of Places, Processes, and Objects in Europe and Beyond, 1450-1650, ed. Susanna Burghartz, Lucas Burkart, Christine Göttler, Leiden 2016, s. 211-239. 
Na podstawie analizy treści wydanego w 1765 r. katalogu aukcyjnego kolekcji naturaliów obu Breyneów wiadomo, że obejmowała ona liczne exsciccatae. I tak obok m.in. „vegetabilia Indica et Japonica rariora, extra chartam exiccata" ${ }^{54}$ znalazły się w niej także zasuszone egzemplarze pruskich roślin rodzimych. Jak zanotowano w katalogu, w trakcie licytacji można było nabyć „eine sehr zahrliche Sammlung von Kräutern sowohl aus beyden Indien, als auch Frankreich, Italien, Holland, Siberien, auch einheimischen, theils von dem berühmten Botanico Jacob Brayne und dessen Sohn Herr D. Joh. Phil. Brayne, in Dantzig und auf ihren Reisen selbst gesammlet, theils auch von Anders Botanicis überschickt, und die Meissten sehr wohl conservirt, alle zwischen 2 Papieren loss liegend, womit 9 grosse und 2 kleine Laden, auch noch etliche Fächer eines Repositorii angefüllet sind" 55 .

W skład Breynowskiej kolekcji exciccatów wchodziły zatem pojedyncze zasuszone egzemplarze roślin zebranych przez obu gdańszczan na terenie Prus Królewskich ${ }^{56}$ i za granicą $\mathrm{w}$ trakcie ich podróż ${ }^{57}$ oraz tych, które zostały im przesłane przez osoby należące do ich „sieci uczonych” ${ }^{58} \mathrm{i} /$ lub członków ich rodzin $^{59}$, a także przekazane przez lokalnych informatorów, m.in. kaszubskie zielarki ${ }^{60}$ czy szwedzkich żołnierzy ${ }^{61}$. W analogiczny sposób zasuszone rośliny z Prus Królewskich oraz innych prowincji należących do Rzeczypospolitej Obojga Narodów były wysyłane przez obu Breyneów do ich uczonych korespondentów z Anglii, krajów niemieckojęzycznych, Niderlandów itd. Przykładowo zasuszone egzemplarze traw z okolic Gdańska zebranych przez Breyne’a Sr. jego syn Johann Philipp wysłał do Johanna Jakoba Scheuzera, z którym jego przyjaciel Christian Heinrich Erndtel urządzał w trakcie swojej tury kawalerskiej herbationes w Alpach ${ }^{62}$. Johann Philipp przekazywał także Hansowi Sloanowi, Williamowi Sherardowi, Jamesowi Petiverowi oraz innym

${ }^{54}$ FB Gotha, Chart. A871, k. 6v.

${ }^{55}$ Herrn Doct. Johann Philipp Brayne nachgelassenen berühmten Naturalien Cabinets welches in Danzig in der Langgasse für baares Danziger Geld den 1765 etc., s. 54; Johann Bernoulli's Reisen durch Brandenburg, Pommern, Preußen, Curland, Rußland und Polen in den Jahren 1777 und 1778, Leipzig 1779, s. 224.

${ }^{56}$ Zob. np. FB Gotha, Chart. A788, k. 47 n.; Chart. B787, k. 492; Chart. B875, s. 170-171.

${ }^{57}$ Zob. np. J. Breyne, Centuria; FB Gotha, Chart. B857b, k. 222v-224; Chart. B968, k. 39, 72, 93; Chart. B 789a, k. 28-33.

${ }^{58}$ J. Breyne, Prodomus I; FB Gotha, Chart. B875, s. 170-171; FB Gotha, Chart. B857b, k. $76 \mathrm{v}-178$.

${ }^{59}$ J. Breyne, Centuria, s. 135, aneks źródłowy nr 1, s. 64.

${ }^{60}$ J. Breyne, Centuria.

${ }^{61}$ Aneks źródłowy nr 1, s. 69.

${ }^{62}$ G. Reyger, op.cit., s. 5; Johann Jakob Scheuchzer, Agrostographia sive Graminum, Juncorum, Cyperorum, Cyperoidum, iisque affinium Historia, Zuerich 1719, passim; K. PęKACKA-FALKowska, Wstęp, s. 16. 
uczonym egzotyczne i pruskie rośliny opisywane m.in. przez ojca w Centurij $^{63}$. Również Jacob Breyne słał swym przyjaciołom obok zasuszonych plantae exoticae rośliny z Kaszub i okolic Gdańska ${ }^{64}$. Niektóre z nich dotrwały do naszych czasów w brytyjskich herbariach Sherarda ${ }^{65}$, Petivera i Sloana ${ }^{66}$. Co równie ważne, obok luźnych zasuszonych roślin umieszczanych między dwoma kartami papieru botanicy wymieniali między sobą także horti sicci przyjmujące formę oprawną, czyli książek-zielników ${ }^{67}$. Czasem nabywali także tego rodzaju kolekcje w trakcie licytacji spuścizn ${ }^{68}$.

Zachowanymi do dziś horti sicci J. Breyne’a, które ten ofiarował w bliżej nieokreślonym czasie swemu patronowi i przyjacielowi Hieronymusowi van Beverningkowi ${ }^{69}$, są dwuczęściowe Herbarium door Jacob Breyne verzameld in de omgeving van Danzig $1659^{70}$ (tytuł wtórny) i czterotomowe Plantae rariores Borussicae et Cassubicae a Jacobo Breynio Gedanensis collectae, exiccatae atq in hoc Libro [1, 2, 3, 4] studio, non eo, quo debebant ordine positae et per nomina Bauhiniana explicatae. An: $1673^{71}$. Zielniki te są nieocenionymi źródłami do badań z zakresu historii botaniki w Rzeczypospolitej Obojga Narodów, florystycznych zainteresowań dawnych gdańszczan czy krążenia wiedzy botanicznej w siedemnastowiecznej Europie.

${ }^{63}$ FB Gotha, Chart. B857b, k. 76v-178. Więcej: K. PęKACKA-FaLkowska, Johann Philipp Breyne i jego ogrody.

${ }^{64}$ The Sloane herbarium: an annotated list, passim; FB Gotha, Chart. A790, k. 49 (prośba od Paolo Boccone o przesłanie egzemplarzy roślin, których nazwy umieścił na liście).

${ }^{65}$ https://herbaria.plants.ox.ac.uk/bol/Sherard; Hermia Newman Clokie, An account of the herbaria of the Department of Botany in the University of Oxford, Oxford 1964, s. 68, https://doi.org/10.5962/bhl.title.137366; Frans Stafleu, Richard S. CowAN, Taxonomic literature, vol. 1: A-G, Utrecht 1976, s. 321-323, https://doi.org/10.5962/bhl.title.48631; G. ThIJssE, „Hieronymus van Beverningk (1614-1690)”. W pracy F. Stafleua (i zesp.) Sherarda utożsamia się ze Stewardem.

${ }^{66}$ The Sloane herbarium: an annotated list, passim.

${ }^{67}$ FB Gotha, Chart. A 785. W herbarium dedykacja: „Collegit \& tom: dedit JOANNI BREYNIO Paulus HERMANNUS: 1683”. Więcej na temat tego herbarium zob. Stephan RAUSCHERT, Das Herbarium von Paul Herman (1646-1695) in der Forschungsbibliothek Gotha, Hercynia N.F., Bd. 7: 1970, s. 301-328; Enid Du Plessis, Mary GunN, The Flora Capensis of Jakob and Johann Philipp Breyne, Johannesburg 1978, s. 15.

${ }^{68}$ Zob. np. Bibliotheca Erndeliana sive Catalogus Librorum Philologico-Medicorum, qvos B. D. Christ. Heinrich Erndel, Sereniss. Augusti II. Reg. Pol. \& El. Sax. Archiater, Adiunctus Academiae Naturae Curiosorum \&c. sibi undecunqve conqvisiverat Auctio fiet Dresdae D. 19. seqq. Jan. MDCCXXXV. In aedium Fridelianarum..., [Dresdae, 1735]. W wystawianym na aukcji pośmiertnej księgozbiorze lekarza przybocznego Augusta II Mocnego wymieniano m.in. herbaria viva sporządzone przez niego i przez Jacoba Theodora Kleina.

${ }^{69}$ G. Thissse, „Hieronymus van Beverningk (1614-1690)”.

${ }^{70}$ Naturalis Biodiversity Center, Leiden, L.2077662.

${ }^{71}$ Ibid., L.2077661. 
Po 1690 r. breyne'owskie horti sicci, zgodnie z ustaleniami Gerarda Thijssego, zostały przekazane zapisem testamentowym z pozostałymi herbariami należącymi do van Beverningka jednemu z jego siostrzeńców - Melchiorowi Gerardowi van Rietveld. Po śmierci tego ostatniego przeszły w ręce kolejnych spadkobierców, by w lipcu 1741 r. trafić do biblioteki Uniwersytetu Lejdejskiego, a następnie Nationaal Herbarium Nederland / Naturalis Biodiversity Centre ${ }^{72}$.

Motywacje, jakie kierowały J. Breynem w trakcie sporządzania wymienionych zielników, nie są znane, zresztą tak jak niewiadome są powody i drogi ich przekazania z Gdańska do niderlandzkich zbiorów jego patrona i zarazem przyjaciela. Być może starsze z gdańskich horti sicci, sporządzone na luźnych kartach czerpanego papieru, gdy J. Breyne miał zaledwie 22 lata, służyły dokumentacji jego botanicznych wycieczek w okolicach Gdańska oraz zestawienia wiadomości o roślinach przekazanych mu przez jego informatorów. Młodsze z zielników, wykonane wtedy, gdy J. Breyne był trzydziestoparolatkiem, to natomiast, jak się wydaje, jedna $\mathrm{z}$ istotnych pomocy do opracowania Pomerelliae Viridarius, za czym mogą przemawiać fragmenty opisów na niektórych etykietkach towarzyszących roślinom ${ }^{73}$. Co także warte podkreślenia, niektóre $\mathrm{z}$ zachowanych $\mathrm{w}$ lejdejskich horti sicci pomorskich roślin zostały opisane przez Breyne’a Sr. w latach siedemdziesiątych XVII w. w jego krótkich doniesieniach drukowanych na łamach "Miscellanea Curiosa”, a także wymienione w Centurii oraz Prodomus (I).

Lejdejskie herbaria J. Breyne’a zawierają łącznie ponad sto (zachowanych w różnym stanie) egzemplarzy zasuszonych roślin z Kaszub i Pomorza. Żadne $\mathrm{z}$ nich nie jest jednak kompletne. W starszym z nich wiele obiektów uległo wykruszeniu, część z nich zostało także wyklejonych lub wyciętych wraz z etykietami. Z czterotomowego herbarium z 1673 r. wycięto natomiast wybrane karty z roślinami, za czym jednoznacznie przemawia nieciągła foliacja. Jak zaznacza Gerard Thijssje, pojedyncze brakujące obiekty mogły zostać usunięte z Breyne’owskich herbariów celowo i włączone do innych kolekcji przechowywanych w Lejdzie ${ }^{74}$.

W herbarium z 1659 r. Breyne Sr zawarł m.in. informacje dotyczące miejsca występowania danej rośliny, czasu jej kwitnięcia czy takich jej cech, jak barwa i zapach, wzorując się na pracach wcześniejszych botaników gdańskich. Ponadto podawał nazwy roślin w języku łacińskim zgodnie z nomenklaturą

${ }^{72}$ G. Thijsse, „Hieronymus van Beverningk (1614-1690)”; Ph. Ch. Molhuysen, op. cit., s. $87-89$.

${ }^{73}$ Por. A. Fleischer, Rooted in fertile soil, s. 112-113.

${ }^{74}$ G. Thijsse, „Hieronymus van Beverningk (1614-1690)”. Thijssje wymienia m.in. lejdejskie herbaria L0144230 i L0365009. 
Caspara Bauhina, przytaczając niekiedy nomina używane przez innych amatorów roślin (np. Julesa Charlesa de l'Écluse’a). Dodatkowe informacje na etykietach stanowiących element mocowania rośliny oraz bezpośrednio na kartach herbarza zapisywał po łacinie i po holendersku. W zielnikach z 1673 r. również używał łacińskiej nomenklatury bauhinowskiej (Caspara i Johanna Bauhinów), jednocześnie podając nazwy używane przez Pierre’a Bellona, Roberta Morisona, Jacobusa Theodorusa Tabernaemontanus, Matthiasa de l'Obel i innych ważnych twórców literatury botanicznej. W przypadku młodszego z zielników uporządkował dodatkowo zasuszone obiekty według kryteriów morisonowskich, co mogło ułatwiać ich identyfikację i grupowanie z innymi egzemplarzami, także tymi w odrębnych kolekcjach ${ }^{75}$. Informacje dodatkowe na etykietach zapisywał tylko po łacinie.

Tabela 1. Siedemnastowieczne herbaria Jacoba Breyne’a

\begin{tabular}{|c|c|c|}
\hline $\begin{array}{c}\text { Numer } \\
\text { inwentarzowy }\end{array}$ & L. 2077662 & L.2077661 \\
\hline 1 & 2 & 3 \\
\hline $\begin{array}{l}\text { Miejsce przecho- } \\
\text { wywania }\end{array}$ & $\begin{array}{l}\text { Naturalis Biodiversity } \\
\text { Center, Lejda }\end{array}$ & $\begin{array}{l}\text { Naturalis Biodiversity Center, } \\
\text { Lejda }\end{array}$ \\
\hline Rok sporządzenia & 1659 & 1673 \\
\hline Oprawa & $\begin{array}{l}\text { Oprawa wtórna - dwie ob- } \\
\text { woluty tekturowe łączone } \\
\text { tasiemkami; } \\
\text { dwa komplety kart } \\
\text { (pars 1, pars 2) - każdy } \\
\text { z kompletów w osobnej } \\
\text { kopercie }\end{array}$ & $\begin{array}{l}\text { Oprawa wtórna (łącząca cztery } \\
\text { oryginalne tomy) w półpłótno, } \\
\text { wiązana (narożniki i grzbiet } \\
\text { płócienne) oklejona papierem } \\
\text { marmurkowym (typ marmurek } \\
\text { „klejowy”) }\end{array}$ \\
\hline Rozmiar & $\begin{array}{l}\text { wys. x szer. x gr.: } \\
53,0 \text { × } 28,8 \text { × } 5,2 \mathrm{~cm} \\
\end{array}$ & $\begin{array}{l}\text { wys. x szer. x gr.: } \\
(39,5+3,5) \text { x } 27,5 \text { x } 5,5 \mathrm{~cm}\end{array}$ \\
\hline Liczba stron & $\begin{array}{l}\text { Pars 1: fol. } 1 \text { - fol. } 28 \\
\text { Pars 2: fol. } 1 \text { - fol. } 16\end{array}$ & $\begin{array}{l}\text { numeracja oryginalna tylko na } \\
\text { kartach z roślinami, atrament: } \\
\text { Vol. 1: ss. } 26 \text {, } \\
\text { numery oryginalne kart } \\
\text { (fol.): } 62,64,67,68,69 ;\end{array}$ \\
\hline
\end{tabular}

${ }^{75}$ A. Fleischer, From the fertile soil, s. 114; Sydney Howard VINEs, Robert Morison and John Ray, [in:] Makers of British Botany. A collection of biographies by living botanists, ed. Francis Wall Oliver, Cambridge 1913, s. 8-43. 


\begin{tabular}{|c|c|c|}
\hline 1 & 2 & 3 \\
\hline & & $\begin{array}{l}\text { Vol. 2: ss. } 22 \text {, } \\
\text { numery oryginalne kart: 45, 46, } \\
48,49,50,51,53,54,55,56,57, \\
58,59,60,61 ; \\
\text { Vol. 3: ss. } 42 \text {, } \\
\text { numery oryginalne kart: 22, 23, } \\
\text { 24, 25, 26, 27, 29, 30, 32, 33, 35, } \\
\text { 36, } 37,39,40,41,42,44 ; \\
\text { Vol. 4: ss. } 26 \text {, } \\
\text { numery oryginalne kart: } 1,2,3,6\end{array}$ \\
\hline $\begin{array}{l}\text { Tytuł na oprawie } \\
\text { [etykieta druko- } \\
\text { wana] }\end{array}$ & $\begin{array}{l}\text { [Herbarium door Jacob } \\
\text { Breyne verzameld in } \\
\text { de omgeving van Dan- } \\
\text { zig 1659] }\end{array}$ & $\begin{array}{l}\text { [Jacob Breynii Plantae rariores } \\
\text { Borussiacae et Cassubieae } \\
\text { An: } 1673 \text { ] }\end{array}$ \\
\hline \multirow[t]{2}{*}{$\begin{array}{l}\text { Tytuł wewnątrz } \\
\text { [rękopiśmienny] }\end{array}$} & brak & $\begin{array}{l}\text { [bs.] } \\
\text { Plantae rariores Borussicae et } \\
\text { Cassubicae a Jacobo Breynio } \\
\text { Gedanensis collectae, exiccatae } \\
\text { atq in hoc Libro Primo studio, } \\
\text { non eo, quo debebant ordine } \\
\text { positae et per nimina Bauhiniana } \\
\text { explicatae. An: } 1673 \text {. } \\
\text { (ACAD LAGB) (5.) }\end{array}$ \\
\hline & & $\begin{array}{l}{[\text { bs.] }} \\
\text { Plantae rariores Borussicae et } \\
\text { Cassubicae a Jacobo Breynio } \\
\text { Gedanensis collectae, exiccatae } \\
\text { atq in hoc Libro Duo studio, } \\
\text { non eo, quo debebant ordine } \\
\text { positae et per nimina Bauhiniana } \\
\text { explicatae. An: } 1673 . \\
\text { (ACAD LAGB) (6.) } \\
\text { [bs.] } \\
\text { Plantae rariores Borussicae et } \\
\text { Cassubicae a Jacobo Breynio } \\
\text { Gedanensis collectae, exiccatae } \\
\text { atq in hoc Libro Tertio studio, } \\
\text { non eo, quo debebant ordine } \\
\text { positae et per nimina Bauhiniana } \\
\text { explicatae. An: } 1673 \text {. } \\
\text { (ACAD LAGB) (7.) }\end{array}$ \\
\hline
\end{tabular}




\begin{tabular}{|c|c|c|}
\hline 1 & 2 & 3 \\
\hline & & $\begin{array}{l}\text { [bs.] } \\
\text { Plantae rariores Borussicae et } \\
\text { Cassubicae a Jacobo Breynio } \\
\text { Gedanensis collectae, exiccatae } \\
\text { atq in hoc Libro Qvarto studio, } \\
\text { non eo, quo debebant ordine } \\
\text { positae et per nimina Bauhiniana } \\
\text { explicatae. An: } 1673 \text {. } \\
\text { (ACAD LAGB) (8.) }\end{array}$ \\
\hline Grzbiet & Nie dotyczy & $\begin{array}{l}\text { Część górna (naklejka, napis } \\
\text { odręczny): } \\
\text { J. Breynii Plantae rariores } \\
\text { Borussiacae et Cassubieae } \\
\text { An: } 1673 . \\
\text { Część dolna (naklejka, napis } \\
\text { drukowany): } \\
\text { Biblithecae Pub. } \\
\text { [fragment uszkodzony]ex } \\
\text { [fragment uszkodzony]nus } \\
\text { No } 1710 .\end{array}$ \\
\hline Indeks & brak & brak \\
\hline $\begin{array}{l}\text { Metoda } \\
\text { mocowania } \\
\text { egzemplarzy }\end{array}$ & $\begin{array}{l}\text { klej i paski papieru oraz } \\
\text { papierowe etykiety }\end{array}$ & $\begin{array}{l}\text { klej i paski papieru oraz } \\
\text { papierowe etykiety }\end{array}$ \\
\hline $\begin{array}{l}\text { Eączna liczba } \\
\text { zachowanych } \\
\text { obiektów }\end{array}$ & 57 & 47 \\
\hline $\begin{array}{l}\text { Liczba zacho- } \\
\text { wanych obiektów } \\
\text { na stronie }\end{array}$ & $1-6$ & $1-3$ \\
\hline $\begin{array}{l}\text { Stan zachowanych } \\
\text { obiektów }\end{array}$ & $\begin{array}{l}\text { dobry, zły (częściowo } \\
\text { wykruszone), bardzo } \\
\text { zły (wykruszone niemal } \\
\text { w całości) } \\
\text { uwaga: brak części } \\
\text { obiektów (całkowicie } \\
\text { wykruszone, wycięte } \\
\text { lub wyklejone wraz z } \\
\text { etykietami) }\end{array}$ & $\begin{array}{l}\text { dobry } \\
\text { uwaga: brak części obiektów } \\
\text { (karty wycięte) }\end{array}$ \\
\hline
\end{tabular}




\begin{tabular}{|c|c|c|}
\hline 1 & 2 & 3 \\
\hline $\begin{array}{l}\text { Nomenklatura } \\
\text { botaniczna }\end{array}$ & $\begin{array}{l}\text { nazwy łacińskie } \\
\text { polinominalne, } \\
\text { pojedyncze greckie } \\
\text { wtrącenia, } \\
\text { informacje uzupełniające } \\
\text { w języku łacińskim i ho- } \\
\text { lenderskim }\end{array}$ & $\begin{array}{l}\text { nazwy łacińskie polinominalne, } \\
\text { pojedyncze greckie wtrącenia, } \\
\text { informacje uzupełniające w języ- } \\
\text { ku łacińskim }\end{array}$ \\
\hline $\begin{array}{l}\text { Miejsce/nośnik } \\
\text { opisu }\end{array}$ & $\begin{array}{l}\text { przyklejona na roślinie } \\
\text { papierowa etykieta i/lub } \\
\text { notatka bezpośrednio } \\
\text { na karcie }\end{array}$ & $\begin{array}{l}\text { przyklejona na roślinie papierowa } \\
\text { etykieta }\end{array}$ \\
\hline Ręka & Jacob Breyne & Jacob Breyne \\
\hline $\begin{array}{l}\text { Opracowanie } \\
\text { obiektów / } \\
\text { uwspółcześnienie } \\
\text { systematyki }\end{array}$ & $\begin{array}{l}\text { wtórne papierowe etykiety } \\
\text { z nazwami łacińskimi } \\
\text { zidentyfikowanych obiek- } \\
\text { tów według systematyki } \\
\text { linneuszowskiej, Simon } \\
\text { Jan van Ooststroom }\end{array}$ & brak \\
\hline Dostęp on-line & brak & brak \\
\hline
\end{tabular}

Źródło: opracowanie własne.

Przechowywane w Lejdzie Breyne’owskie horti sicci mają obecnie znaczenie historyczne. Niemniej mogą być przydatne historykom i filozofom nauki oraz botanikom i etnobotanikom badającym dawne systemy klasyfikacyjne albo śledzącym historię flory rodzimej wczesnonowożytnej Rzeczypospolitej czy południowego wybrzeża Bałtyku. Źródła te mogą zostać wykorzystane również przez historyków sztuki studiujących ilustracje naukowe (przede wszystkim botaniczne), przedstawicieli environmental history koncentrujących się na zmiennych relacjach między człowiekiem a środowiskiem naturalnym na przestrzeni ostatnich stuleci oraz badaczy innych specjalności.

W przygotowaniu tekstu zielników do druku korzystano częściowo $\mathrm{z}$ instrukcji wydawniczej Empfehlungen zur Edition frühneuzeitlicher Texte vom Arbeitskreis „Editionsprobleme der Frühen Neuzeit" ". Rozwiązywano tylko niektóre abrewiacje, zaznaczając to w tekście. Zaznaczano także, czy opis danej rośliny pojawił się na mocowanych etykietach, czy bezpośrednio na papierze i czy towarzyszył mu zasuszony egzemplarz danej plantae. Oszczędność miejsca w druku zadecydowała o nieoddawaniu oryginalnego układu tekstu, tyl-

\footnotetext{
${ }^{76} \mathrm{http}: / /$ www.heimatforschung-regensburg.de/280/1/E-Forum_AHF-Empfehlungen.pdf (dostęp z 19 IX 2018 r.).
} 
ko zastąpieniu go własnym, wprowadzonym przez wydawcę, uporządkowaniem graficznym.

Dziękuję Christel Schollaardt, Hoofd Collectie Botanie, i Roxali Bijmoer, Senior Collections Manager, z Naturalis Biodiversity Center w Lejdzie za umożliwienie przeprowadzenia kwerendy w kolekcji herbariów historycznych oraz Gerardowi Thijsee za udostępnienie maszynopisu niepublikowanego artykułu „Hieronymus van Beverningk (1614-1690), diplomat and plant lover. His garden and herbaria, in particular those of Paolo Boccone (1633-1704), Jacob Breyne (1637-1697) and Paul Hermann (1646-1695)".

\section{ANEKS NR 1}

HeRbarium J. BREYNE'A Z 1659 ROKU

[Herbarium door Jacob Breyne verzameld in de omgeving van Danzig 1659] Naturalis Biodiversity Center, Lejda, sygn. L.2077662

Uw.: odpisy opublikowane $\mathrm{z}$ pojedynczymi błędami przez: Simon Jan vaN Ooststroom, Een 17de eeuwsch herbarium uit de omgeving van Danzig, [in:] Gedenkboek J. Valckenier Suringar, 24 December 1864 - 17 October 1932, Wageningen 1942, s. 212-217.

\section{Część 1}

Fol. 1

a-ACAD LVGD ${ }^{-a}$

[fragmenty wykruszonej rośliny]

[na papierze zapisane] Hedisarum peregrinum Clusii

Fol. 2

[trzy fragmenty roślin] [na papierze] Gentiana palustris latifolia flore punctato. Cas. Bauhini ${ }^{77}$. in Pinace ${ }^{78}$. Sive Alisma folio glabro. in Phytopinace ${ }^{79}$. Collegi. Ao 1659. M. Augusto.

${ }^{\mathrm{a}-\mathrm{a}}$ pieczęć

${ }^{77}$ Caspar Bauhin (1560-1624) - szwajcarski naturalista, wprowadził binominalny system klasyfikacji do anatomii i botaniki.

${ }^{78}$ Caspar Bauhin, Pinax theatri botanici, Basileae Helvet. 1623.

${ }^{79}$ Idem, Phytopinax seu Enumeratio plantarum ab Herbariis nostro seculo descriptarum, cum earum differentiis: cui plurimarum hactenus ab iisdem non descriptarum succinctae descrip- 
NB. hier bennen 2 soorten in fatzoen van bloemen verschillende

No. 1. is dese die UE sende, heeft groote en heel scherpe spitz biadige bloemen, No. 2 waer van hier, een bloemche leit, de welcke kleiner, ende botter. In de coleur is oock een verschil, als. bleick. 2. blauw. 1. brujjn, de placken (?) bennen doorgaens een coleur.

N. 2.

Fol. 3

[usunięte trzy rośliny, pozostałości po trzech etykietkach]

[karta nienumerowana]

[na papierze] Gentiana cruciata major.

[karta nienumerowana]

[roślina bez etykiety]

Fol. 4

[zasuszona roślina] [na papierze] Teucrium

Fol. 5

[zasuszona roślina] [na etykiecie] Chamaecist[us] flore luteo ${ }^{\mathrm{b}} \mathrm{C}$. B. ${ }^{\mathrm{b}}$ sive. Panax Chironicu[m] Matthiol. ${ }^{80} \mathrm{M}$. Julio, in collib[us] inter desertum Bahrenwinckel et Jaskendahle

[zasuszona roślina] [na etykiecie] Selago tertia. Thalii. ${ }^{81}$ sive musc[us] erect[us] ramos[us] saturate viridis, granula inter folia haben. C.B. Rara est plantula et reperi in montib[u]s sylvosis bej Mattaren. [na papierze] NB. Dese Muscus dryefft soo sterck als Sabina

[zasuszona roślina] [na etykiecie] Polygonum ${ }^{\mathrm{c}}$ Polyg. Coccife[r]u[mignes].

M. Julio, copiose in montib[us] apricis. Juxta. Pagu[m] Bringenzii

[zasuszona roślina] [na etykiecie] Vaccinia. Pannonica. Gesn. ${ }^{82}$ Trunckel beren. In udosis Insul: Nerring: [na papierze] Op het vel is geschreven: Als men veel van dese peeren eet soo wordt men soo droncken als off men veel wjjn gesoopen hadde.

tiones \& denominationes accessere: Additis aliquot hactenus non sculptarum plantarum vivis iconibus: / Casparo Bauhino Botanico \& Anatomico Acad. Basileens. ordin. Auctore, Basileae 1596.

b-b inicjały nadpisane

c dwa wyrazy skreślone

${ }^{80}$ Pietro Andrea Gregorio Mattioli (Matthiolus) (1501-1577) - włoski naturalista, interesował się m.in. botaniką medyczną, edytor prac botanicznych Dioskurydesa.

${ }^{81}$ Roślina opisana przez J. Breyne’a w: idem, Obs. CXLIX: De Selagine tertia thalii, Miscellanea Curiosa, An. 4-5: 1673/1674, Dec. I, s. 198.

${ }^{82}$ Conrad Gesner (1516-1565) - szwajcarski naturalista zainteresowany m.in. botaniką, autor Historia Plantarum. 
Fol. 6

[zasuszona roślina] [na etykiecie] Cist[us] Ledon foliis rorismarini ferrugineis. C. Bau.

NB. de Schweden hebben van dit kruyt wel 10 voeder uyt de Neeringh gehalt, om in het bier voor de Soldaten te doen twelck furiesigkeit maekt

[zasuszona roślina] [na etykiecie] $\operatorname{Fer}[\mathrm{r}] \mathrm{u}[\mathrm{m}]$ equinu[m] siliqua singulari. C. Bau. Sive. Sferro cavallo. Adversar: Solea equina. In historia generalis lugduni cusa ${ }^{83}$

[zasuszona roślina] [na etykiecie] Anonymos tenuifolia. Clus ${ }^{84}$ sive. Anthyllis montana. in histor. gener. lugduni cusa. Floret mense Junio in montib[us] inter ericas prope desertum Bahrenwinckel. Sed in montib[us] non procul pa$\mathrm{gu}[\mathrm{m}]$ bringen $\mathrm{zu}$ ad semicubitu[m] crescit.

[zasuszona roślina] [bez etykiety]

[zasuszona roślina] [na etykiecie] Viola barbata angustifolia. Dalechampii ${ }^{85}$. Floret M. Julio in monte isto herboso inter veperes juxta patibulu[m].

Fol. 8

[zasuszona roślina] [na etykiecie] Origanu[m] specious[m]. M. Julio et Augusto. reperi copiose in colle isto herboso inter veperes prope patibulu[m]

[zasuszona roślina] [na etykiecie] Chamaenerion Gesnerii flore albo. Rara est planta, et nullibu[s] nisi tantu[m] in deserto vulgo bahren winckel. adhuc observavi. ubi etiam college

[usunięta rośliny, pozostałości po etykiecie]

Fol. 9

[usunięte dwie rośliny, pozostałości po jednej etykiecie]

[zasuszona roślina] [na etykiecie] Rapuncul[us] spicat[us] flore albo. In sylvis ac sylvosis montib[us]. M. Julio.

Fol. 10

[usunięte dwie rośliny, pozostałości po etykietach]

Fol. 11

[usunięte trzy rośliny, pozostałości po etykietach]

${ }^{83}$ Jacques Dalechamps, Historia generalis plantarum [...] [Pars prima], Lugduni 1586.

${ }^{84}$ Jules Charles de l'Écluse (Clusius) (1526-1609) - francuski lekarz i botanik, działający we Flandrii, jeden z najważniejszych botaników XVI w. Jako pierwszy w historii stworzył naukowe opisy gatunków roślin.

${ }^{85}$ Jacques Dalechamps (1513-1588) - francuski lekarz i botanik, korespondent Gesnera. 
Fol. 12

[usunięta rośliny, pozostałości po etykiecie]

[zasuszona roślina] [na etykiecie] Pyrola rotundifolia major fol. ampliore mollique Cas. Bau.

M. Julio ad margin. sylvaru[m].

[zasuszona roślina] [na etykiecie] Stoebe Austriaca. Clusii. In collib[us] ac montib[us] herbosis inter frutices in deserto Bahren winckel. M. Augusto

[karta nienumerowana]

[fragment trzech zasuszonych roślin bez etykiet]

Fol. 15

[usunięta rośliny, pozostałości po etykiecie]

[zasuszona roślina] [na etykiecie] Pyrola. rotondifolia. folio minore et atrovirose. flore luteo virescente. inodor. M. Julio. In ista spelunca ubi Calceolus Mar. ${ }^{86}$ cres., et etiam in sylv. Jasken:

Fol. 16

[usunięte dwie rośliny, pozostałości po etykiecie]

Fol. 17

[usunięte trzy rośliny, pozostałości po etykiecie]

Fol. 19

[zasuszona roślina] [na etykiecie] Scorzonera montana humilis latifolia. J. B. ${ }^{87}$ M. Majo. In montib[us] inter ericae in deserto Bahren winckel.

[zasuszona roślina] [na etykiecie] Hyraciu[m] Pannonicu[m] latifoliu[m] ma$\mathrm{j}$ [us] folio non maculato. In montib[us] in deserto Bahren winckel.

Fol. 20

[usunięta rośliny, pozostałości po etykiecie]

[zasuszona roślina] [na etykiecie] Hyracium mont, latifol. Clusii folio macul. M. Junio in collib[us] et montib[us] herbosis in deserto Bahren winckel [zasuszona roślina] [na etykiecie] Fungus ramos[us] Imperati. S. Digitelli. M. Aug[usto] in sylvis ubi dodrantem non superat [na papierze] Van deze

${ }^{86}$ Roślina opisana przez J. Breyne’a w: idem, Obs. CCLXXXIX: De musco pulmonario..., Miscellanea Curiosa, An. 3: 1673, Dec. I., s. 509-511.

${ }^{87}$ Jean Bauhin (Johann Bauhin) (1541-1612) - szwajcarski naturalista i botanik, brat Caspara Bauhina. 
Manninae worden 3 soorten gevonde. No. 1 is dese en geel von coleur. No. 2 is grauw. No. 3 is wit.

[zasuszona roślina] [na etykiecie] Lactucella sylv. repens. Camerar. ${ }^{88} \mathrm{M}$. Julio. op een weide achter de Oliwe niit ver van Ambrosie syn hoff, al de waer de diverse Satiyria staen.

Fol. 21

[usunięta rośliny, pozostałości po etykiecie]

[zasuszona roślina] [na etykiecie] Dauc[us] montan[us] hirsute[us]. M. Augusto. in montib[us] ubiq[ue]

Fol. 22

[usunięte dwie rośliny, pozostałości po etykiecie]

Fol. 23

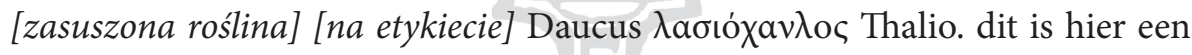
rare plante, ende groeit opt geberchte achter Miggauw

[zasuszona roślina] [na etykiecie] Meu[m] alteru[m] Silesiacu[m]. Cam. flore amethistino. dese aerdige aromatische plant in een lustigh bosche ontrent Bringenzii. in Junio en Julio.

[na papierze] Myrris altera parva lobelii

Fol. 24

[na papierze] Orobanche quib[us]da[m] Hypopitis flore sulphureo lanuginoso.

[zasuszona roślina bez etykiety]

[usunięte dwie rośliny, pozostałości po etykietach]

[fragment rośliny] [na etykiecie] Testicul[us] vulpin[us]. Op het geberch in de woestine de bahren winckel. bloeidt ontrent Junio in grote abundansie

Fol. 25

[fragment rośliny] [na etykiecie] Phalangiu[m] ramosu[m]. M. Julio et Augusto. In montibus Juxta Monasterium Oliwe

[fragment rośliny] [na etykiecie] Spartu[m] 3. lobelii. M. Julio, super montem vulgo de wunderberge

[fragment rośliny] [na etykiecie] Juncus alpinus capitulo lanuginoso. M. Majo. In Insula Nerringa [na papierze] Juncus alpin[us] cu[m] cauda leporina C. Bau. NB. dit is heel raer, en diendt te weeten dat het nijt linu[m] pratense is.

${ }^{88}$ Joachim Camerarius (1534-1598) - niemiecki naturalista i botanik, autor Hortus medicus et philosophicus in quo plurimorum stirpium brevis descriptio (1588). 
[fragment rośliny] [na etykiecie] Serapias minor rubello ni ${ }^{\mathrm{d}}$ flore ${ }^{-\mathrm{d}}$ tente flore angustiiolia nullis inspersis punctulis ${ }^{\mathrm{e}}$ lobelii.

M. Julio in montib[us] inter ericas.

Fol. 26

[usunięte dwie rośliny, pozostałości po etykietach]

[karta nienumerowana]

[usunięte dwie rośliny]

[na papierze] flos semen

[karta nienumerowana]

[na papierze] Muscus terrestris clavatus C. B. Lycopodium. s. Pes Lupi. Selago 2. Thalii.

[na papierze] Groeidt in grote abundantie op het boschachtige geberghte ter Oliwe;

[na papierze] Lycopodium. s. Pes Lupi.

Fol. 27

[na papierze] Ledon Sijlesiacum Clus. sive. Rosmarinus sylvest. Dodo. ${ }^{89}$ sive. Chamaepeuce Cordi. ${ }^{90}$ sive. Cistus ledon foliis rorismarini ferrugineis C. Bau. [na papierze] De Schweden hebben van dit Hesterchen wel 20 Voeder uijt de Neringh in het Hooft laeten voeren, om in het bier voor de Soldaten te doen, dan het heeft een Furiesmaekende kracht.

\section{[karta nienumerowana]}

[na papierze] Ao. 1659. dese hebbe dit Jaehr noch toe gedaen. Pulsatilla ranunculi folio obtusiore. Jacobi Breynii. sive. Pulsatilla folio annemones secundae Cas. Bau.

NB. Flos est coeruleus odorat[us].

[na papierze] Floret M. Majo in montibus circa Thoruniam unde Jacobus Hase misit. sub nomine. Pulsatilla coerulea odoratissima. reperitur etiam in ericetis bey Beren. ${ }^{91}$

[na papierze] Lichen petrae: fol. supern. virid. prona parte alb : nervis nigris distinctis foliorum extremis orbiculis nigris tumidis. Eeperi $\mathrm{cu}[\mathrm{m}]$ suis orbiculis onustis. M. Majo in montib[us] Oliwiensis.

d--d fragment skreślony

${ }^{\mathrm{e}}$ fragment skreślony

${ }^{89}$ Rembert Dodoens (1517-1585) - lekarz i botanik flamandzki.

${ }^{90}$ Euricius Cordius - niemiecki botanik, autor Iudicium de herbis et simplicibus medicinae.

${ }^{91}$ Roślina opisana przez J. Breyne’a w: idem, Centuria, s. 135. 
[na papierze] Pulsatilla vernalis apii folio flore majore. [na papierze] Pulsatilla flore clauso coeruleo. Joh. Bauh. NB. Ick hebbe dit Jaehr dese Pulsatilla met schwart brtujne bloemen gevonden. Item eene de welcke licht aschgrauw is ende de voorste spitsen van de blaeden bruyn.

\section{Część 2}

[k. nienumerowana $\mathrm{v}]$

a-AGAD LVGD

[k. nienumerowana r]

[na papierze] Gnaphalium Creticum non descriptum Gnaphalium maximum; Helyochryson Orientale C. Bau.

\section{Fol. 2}

[usunięte dwie rośliny, pozostałości po etykietach]

Fol. 2

[usunięte dwie rośliny, pozostałości po etykietach]

[fragment rośliny] [na etykiecie] Stoechas rubescens, bloeyt op het Oliwsche geberchte in Augusto, ende wordt seiden gevonden

[na papierze wyraz skreślony nieczytelny]

\section{Fol. 3}

[usunięte dwie rośliny, pozostałości po etykietach] [fragment rośliny] [na etykiecie] Origanum speciosu[m]. sive. varietas. Op een bergh soo achter de galghe staedt. in. Augusto

Fol. 4

[usunięte dwie rośliny, pozostałości po etykietach] [fragment rośliny] [na etykiecie] Veronica flore candido. dit raere plantene groeit ontrent, Beeren, in de wouden, ende bloeidt. in. Junio en Julio [na karcie] De bloem is spierwit maer wordt in het opdrogen ros.

Fol. 5

[usunięte dwie rośliny, pozostałości po etykietach] [fragment rośliny] [na etykiecie] Vaccinia Pannonica. Ger. In Insula Nerringa

${ }^{\mathrm{a}-\mathrm{a}}$ pieczęć 
Fol. 6

[usunięte dwie rośliny, pozostałości po etykietach]

[fragment rośliny] [na etykiecie] Vicicia dumetoru[m] maxima, multiflora, flore albo, venulis purpureis, elegantissimis striatis, ut in Geranio Virginiano. Dese raere plante groeit In Julio. In de dunker bergachtige Buschen.

[karta nienumerowana]

[na papierze] NB. Als dese Nidus avis noch op seyn best staedt en bloeydt, soo heeft het dese selwdige vahle colour, die het nou heeft, want wortel, steel, blaeden en bloem is een coleur.

[usunięte dwie rośliny, pozostałości po etykietach]

Fol. 8

[usunięta roślina, pozostałość po etykiecie]

[fragment rośliny] [na etykiecie] Aster montan[us] lute[us] Salicis glabro folio. C. Bau. In Augusto op het geberchte [fragment rośliny] [na etykiecie] Lactucella sylvestris repens. Camerar. M. Julio. in pratis Oliwiens:

\section{[karta nienumerowana]}

[usunięte trzy rośliny, pozostałości po etykietach]

Fol. 10

[usunięta roślina, pozostałość po etykiecie]

[fragment rośliny bez etykiety]

[fragment rośliny] [na etykiecie] Ranuncul[us] ${ }^{92}$ montanu[s] subhirsut[us] Latifoli[us] C.B. In de Valleien, aan de kanten, van de loopende fonteinen in Junio.

Fol. 11

[roślina usunięta, pozostałość po etykiecie]

[na papierze] NB. dese soorte met bredere blaederen kan Ut bey Sr. Hermanus van den Burch siyn.

Fol. 12

[roślina usunięta, pozostałość po etykiecie] [na papierze] NB. dese soorte met schmalle blaederen kan Ut bij mijn Cos. Johan Breynne syen.

[fragment rośliny] [na etykiecie] Meum alteru[m] Sylesiacu[m]. Cam. flore amethistino.

${ }^{92}$ Roślina opisana przez J. Breyne’a w: idem, Prodomus I, s. 45. 
Dit sterekruickende aromatische plantche groeidt In Julio in de Bahren winckel by Bringenzii.

Fol. 13

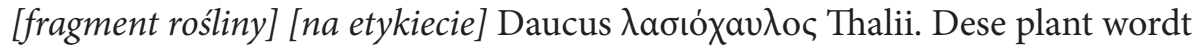
weinigh gevonden dr groeit op de bergen onder de heide achter Miggauw in. Julio en Augusto.

[roślina usunięta, pozostałość po etykiecie]

Fol. 14

[usunięte trzy rośliny, pozostałości po etykietach]

[fragment rośliny bez etykiety]

[fragment rośliny] [na etykiecie] Thalictru[m] B. angustifolium Cam. Heet seiden wordt dese plante hier gevonden en groeit niet verre van Beeren, bloeidt in Julio.

[karta nienumerowana]

[na karcie] Alisma Tassani Caroli Johannis Bauhini. sive Gentiana. 12. et punctata. Clusii.

\section{[karta nienumerowana]}

Leontopodium Creticum; Leontopodium Matthioli; Gnaphalium roseum hortense; Leontopodium alterum lob.; Gnaphalium Roseum sylvest.; Gnaphalium unciale Hispanicu.

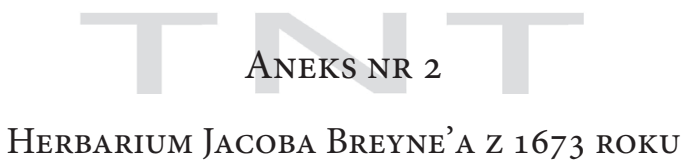

[Plantae rariores Borussicae et Cassubicae a Jacobo Breynio Gedanensis collectae, exiccatae atq in hoc Libro Tertio studio, non eo, quo debebant ordine positae et per nimina Bauhiniana explicatae. An: 1673.]

Naturalis Biodiversity Center, Lejda, sygn. L.2077661

[karta nienumerowana]

[na karcie] Num V.

[na etykiecie] Plantae rariores Borussiacae et Cassubicae à Jacobo Breyni Gedanensi Collectae, exsiccatae ataq. In hoc Libro Primo studio., non eo, quo debebant ordine propositae et per nomina Bauhiniana explicatae An: 1673 [pieczęć okragła] Acad. Lugd. Bat. Bibl.

[na karcie] 5. [pieczęć] ACAD LUGD 
Fol. 62

[fragment rośliny] [na etykiecie] Viscum, Johannis Bauhini, Viscum baccis albis, Casp. Bauh:

Fol. 64

[fragment rośliny] [na etykiecie] Cornus foemina, putata Virga Sanguinea, Joh Bauh: Cornus foemina, Casp Bauh: Fractex sanguine, Bellonii ${ }^{93}$

Fol. 67

[fragment rośliny] [na etykiecie] Ledum Silesiacu[m] ${ }^{94}$ cum fructibus.

Fol. 68

[fragment rośliny] [na etykiecie] Chamoerhododendros Montana Allobrogum Oleastrifolio, seu Lentisci folio minus odora, Lobelli95

Fol. 69

[fragment rośliny] [na etykiecie] Caryophyllata Montana tertia Clusii ${ }^{96}$, flore pleno prolifero, Jacobi Breynii in Viridae: Bous:

[karta nienumerowana]

[na karcie] Num VI. 6

[na etykiecie] Plantae rariores Borussiacae Et Cassubicae à Jacobo Breyni Gedanensi Collectae, arte exsiccatae ataq. In hoc Libro Secundo Studio., non eo, quo debebant ordine propositae et per nomina Bauhiniana explicatae An: 1673 [pieczęć okragła] Acad. Lugd. Bat. Bibl. [na karcie] 6. [pieczęć] ACAD LUGD

Fol. 45

[fragment rośliny] [na etykiecie] Vicia dumetorum Maxima seicata, Multi floribq ${ }^{97}$ candidis venis purpur eis distinctis; Vicia hancpulcherrimam in Viridario Borussiaco et Casubico describimq.

Fol. 46

[fragment rośliny] [na etykiecie] Vicia minima vernalis radice tuberose, de qua in Viridario nostro Borrusiaco. An Vicia praecox venna, minima Sloniensis, semine hexedro Morison[n]i.

${ }^{93}$ Pierre Belon (1517-1564) - francuski naturalista i dyplomata zainteresowany m.in. botaniką. Autor m.in. De arboribus Coniferis, Resiniferis aliisque semper virentibus (1553).

${ }^{94}$ Roślina opisana przez J. Breyne’a w: Miscellanea Curiosa, An. 3: 1672, s. 511.

${ }^{95}$ Mathias de l'Obel, Mathias de Lobel (Matthaeus Lobelius) (1538-1616) - flamandzki lekarz i botanik.

${ }^{96}$ Roślina opisana przez J. Breyne’a w: idem, Centuria, s. $130 \mathrm{n}$.

${ }^{97}$ Roślina opisana przez J. Breyne’a w: idem, Prodomus I, s. 52. 
Fol. 48

[fragment rośliny] [na etykiecie] Onobrychis X floribq. Viciae dilute coeruleis, casp: Bauh: Onobrychis qvibusdam subcoeruleo flore, Joh: Bauh: Onobrychis Secunda, Clusii. Qvam raro a Clusio in Austria; tam copiose in loco avenostro quodam Cassubiae a me reperta.

Fol. 49

[fragment rośliny] [na etykiecie] Junc[us] alpin[us] cum cauda Leporina, Joh: Bauh: Junc[us] alpin[us] capitulo lanuginoso, C. Buhini in Prod:

Fol. 50

[fragment rośliny] [na etykiecie] Gramen nemorosum hirsutu[m] primum, sive latifolium majq., Casp: Bauhini Gramen rore lucidum nemoroese, sive Luzulae, J: Bauh: Gramen hirsutum nemorosum, Lobelii

Fol. 51

[fragment rośliny] [na etykiecie] Gramen nemrosum hirsute. quartu., sive Gramen hirsutum capitulo globoso, C.B: Gramen Lucidum, Taber ${ }^{98}$ : Gramen capitulo lucido globoso Tabernaemontani, Joh. Bauhini.

Fol. 53

[fragment rośliny] [na etykiecie] Gramen Sylvaticu. parvu. tenuifolium rigidiusculum, Joh: Bauhini. Gramen nemorosum globm. 3, sive Gramen nemorosu. Spica ruffescente molli, C.B.

Gramen nemorosum 1, Tab:

$$
\text { Fol. } 54
$$

[fragment rośliny] [na etykiecie] Gramen spicatum montanum et nemorosum 4, sive Gramen caryophyllatum montanum Spicae varia, Caspari Bauhini. Gramen caryophyllatum montanum Spica varia Caspari Bauhini, Joh: Bauh:

Fol. 55

[fragment rośliny] [na etykiecie] Gramen Mariae odoratum, Joh: Bauh: Gramen paniculatum montanu[m] 2, sive Gramen paniculatum odoratum, casp: Bauh. Icon apud Johannem et Casparum Bauhinu[m], à planta in cedis nata malefacta, parvum valet: at Gramen glumis variis, Casp: Bauh: nihil aliud, qvam Gramen Mariae hoc in [skreslone] montosis collectum. Apu nos in Prussia adetanik.

${ }^{98}$ (Jacobus Theodorus) Tabernaemontanus (1522-1590) - niemiecki lekarz i aptekarz, bo- 
nodum copiose oritur, et à mulierculis rizotomis primo vere infassiculis venale odoris gratia affertur.

Fol. 56

[fragment rośliny] [na etykiecie] Gramen nemorale avenaceum alterum ex fusco xerampelinum et lucidu[m] Danicum, Adver: et Joh: Bauhinia: Gramen avenaceum 4, sive capillaceum minoribq glumis, Caspari Bau:

Fol. 57

[fragment rośliny] [na etykiecie] Perfoliata alpine magna, langifolia, Joh: Bauh: Perfoliata Montana latifolia, Caspari Bauhini. Perfoliata Montana, Camerarii

Fol. 58

[fragment rośliny] [na etykiecie] Meum Silesiacum, Camerarii, flore amethistino. Cicutaria latifolia hirsuta, flore amethistino, Joh: Bauh: ${ }^{99}$ Cicutaria paluferis, latifolia rubore, Casp: Bauhini.

Fol. 59

[fragment rośliny] [na etykiecie] Apium petroleum, sive montanum album, Joh: Bauhini, tenujoribq foliis.

Fol. 60

[fragment rośliny] [na etykiecie] Apium petroleum, sive montanum album, Johannis Bauhini latiore folio. Dancq montanq Apiifoli [skreślone] mino. Casp: Bauh: in Prod: icon: Dancq montanq Apiifolio albicans, Casp: Bauh: in Pin:

Fol. 61

[fragment rośliny] [na etykiecie] Thalictrum septimu[m], sive Thalictrum praterse angustissimo folio, Casp: Bauh:

[karta nienumerowana]

[na karcie] Num VII. 7

[na etykiecie] Plantae rariores Borussiacae Et Cassubicae à Jacobo Breynio Gedanensi collectae, arte exsiccatae atq. In hoc Libro tertio studio., non eo, quo debebant ordine prositae et per nomina Bauhiniana explicatae An: 1673 [pieczęć okragła] Acad. Lugd. Bat. Bibl.

[na karcie] 7 [pieczęć] ACAD LUGD

${ }^{99}$ Roślina opisana przez J. Breyne’a w: idem, Prodomus I, s. 29. 
Fol. 22

[fragment rośliny] [na etykiecie] Stoechas citrina Germanica latiore folio, Joh: Bauhini. Elichryson VII, sive Stoechas citrine latifolia, Casp: Bauh: Amaranth[us] lute[us], Fuchsii, Tragi ${ }^{100}$, primq Tabernaemont:

Casparq Bauhinq in Pinace. Haec etiam c[u]m Helichryso 4 quae Stoechas citrine tenuifolia Narbonensis, J; Bau: confundit.

Fol. 23

[fragment rośliny] [na etykiecie] Stoechas citrina Germanica latiore folio, squamulis corymboru. Minoribq.

Fol. 24

[fragment rośliny] [na etykiecie] Stoechas aurea Germanica. Colorem medium inter praededentem citrinam, et seqventem ignstentem obtinet

Fol. 25

[fragment rośliny] [na etykiecie] Stoechas ruffa, sive colore igneo Cassubica Latiore folio.

[fragment rośliny] [na etykiecie] Stoechas ignescens ${ }^{101}$, sive ruffa Casibica Latiore folio.

Descriptio cum praecedentis, in Viridario Borussiaco et Historia exoticarum sequentur.

[fragment rośliny] [na etykiecie] Stoechas ruffa, sive colore igneo Cassubica Latiore folio.

Fol. 26

[fragment rośliny] [na etykiecie] Gnaphalium ad Stoechadem citrinam accedens, Johannis Bauhini. Helichrysum 8, sive Elichrysum Sylvestre latifolium capitulis conglobates, Cas: Bauh:

Fol. 27

[fragment rośliny] [na etykiecie] Gnaphalium medium, Tabernaemontani. Gnaphalio vulgari simile, Johannis Bauhini. Gnaphalium 4, sive mediu[m], Caspari Bauhini.

${ }^{100}$ Hieronim Bock zwany Tragus (1498-1554) - duchowny luterański i botanik, autor New Kreuterbuch von Underscheidt, Würckung und Namen der Kreuter, so in teutschen Landen wachsen.

${ }^{101}$ Roślina opisana przez J. Breyne’a w: Miscellanea Curiosa, An. 4/5: 1673, s. 144; idem, Centuria, s. 145. 
Fol. 29

[fragment rośliny] [na etykiecie] Gnaphalium montanum flore rotundiore candido, Caspari Bauhini. Gnaphalium montanum album, Lobelii. Pilosella major flore candido, Joh: Bauhini.

Fol. 30

[fragment rośliny] [na etykiecie] Gnaphalium montanum flore rotundiore roseo, Caspari Bauhini. Pilosella major flore magis puprurasante, Joh: Bauhini

Fol. 32

[fragment rośliny] [na etykiecie] Gnaphalium montanum longiore flore purpureo. Pilosella minor flore purpurante, Johannis Bauhini.

Fol. 33

[fragment rośliny] [na etykiecie] Gnaphalium montanum longiore flore purpureo, punctulis nigris insperis. Notandum: Qvia Casparq Bauhinq Gnaphalio montano longiore flore, etiam folia angustiora, qvam flore rotundiore adscribit: ideo à fratre Johanne reprettrenditur, qvod inter folia nullu., sed inter flores potissimum discrimen at quod haec Gnaphalia praedicta cum brevioribq longioribq q floribq affirmant. Reperitur vero hic quaedam etiam species cum floribq longioribq, cujq folia angustiora, uti a Casparo Bauhino annotatu.: de quo in nostro Viridario Borussiaco plura.

Fol. 35

[fragment rośliny] [na etykiecie] Pilosella minoris flore, hirsutior et elatior non repens, Johannis Bauhini. Pilosella major erecta, Casp: Bauh: An Hieracium XXII sive murorum angustigolium non sinnatu., Casp: B: in Prodomo.

Fol. 36

[fragment rośliny] [na etykiecie] Hieracium montanu[m] hirsute[m] VI, sive Hieracium alpine $[\mathrm{m}]$ latifolium hirsutie incanu[m] flore magno, Casp: Bauh: Hieracium latifoliu[m] 1, Clusii; Hieraciu[m] latifoliu[m] Pannonicu[m], cam: Hieraciu[m] Pannonicum latifoliu[m] 1 Clussio, Pilosellaemajori, sive Pulmonariae luteae accidens, Joh: Bauh.

Fol. 37

[fragment rośliny] [na etykiecie] Hieracium caule aphyllo hirsutum, Joh: Bauhini, folii latioribq.

Fol. 39

[fragment rośliny] [na etykiecie] Hieracium fruticosum angustifolium minimu[m]: quos Hieracium fruticosum VI in Viridario Boruss: 
Fol. 40

[fragment rośliny] [na etykiecie] Hieracium fruticosu[m] angustifoliu[m] medium combellatum: qvod Hieracium fruticosum V, in Viridario Borussiaco.

Fol. 41

[fragment rośliny] [na etykiecie] Scorzonera Latifolia 4, sive humilis nervosa, Casp: Bauhini. Scorzonera humilis latifolia Pannonica 2, Clus: Tragopogonis Species, sive Scorzonera humilis latifolia, Johannis Bauhini

Fol. 42

[fragment rośliny] [na etykiecie] Scorzonera angustifolia prima, Caspari Bauhini. Scorzonera humilis angustofolia et Pannonica tertia, Clusii. Tragopogonis species, sive Scorzonera humilis angustofolia, Johannis Bauhini.

Fol. 44

[fragment rośliny] [na etykiecie] Stoebe Gallica et Austriaca, Cl. Stoebe foliis laciniatis 3, sive Stoebe major caliculis non splendentibq, Caspari Bauhini. Centaurii majoris species tenuifolia, Johannis Bauhini. Ratione loci variat; unde a Clusio in elatiorem et humiliorem distinqatur.

\section{[karta nienumerowana]}

[na karcie] Num VIII. 8

[na etykiecie] Plantae rariores Borussiacae et Cassubicae à Jacobo Breynio Gedanensi

Collectae, arte exsiccatae ataq. In hoc Libro Quarto studio., non eo, quo debebant ordine propositae et per nomina Bauhiniana explicatae An:1673 [pieczęć okragła] Acad. Lugd. Bat. Bibl.

[na karcie] 8 [pieczęć] ACAD LUGD

Fol. 1

[fragment rośliny] [na etykiecie] Eahium montanum floreex dilute coerulo et albo variegato. Apud nos, in Cassubia sed raro reperitur.

Fol. 2

[fragment rośliny] [na etykiecie] Echium montanum flore purpuro violaceo

Fol. 3

[fragment rośliny] [na etykiecie] Echium montanum flore carneo. 
Fol. 6

[fragment rośliny] [na etykiecie] Alysson 2, sive Thlaspi Alysson dictum campestre minq, Caspari Bauhini. Ayssum minimum, Clusii, Thlaspi minq quibqdem, aliis Alysson minq, Joh: Bauh:

Nadesłany 5 V 2018

Nadesłany po poprawkach 17 IX 2018

Zaakceptowany 28 IX 2018

Dr Katarzyna Pękacka-Falkowska

Katedra i Zakład Historii i Filozofii Nauk Medycznych

Uniwersytet Medyczny im. Karola Marcinkowskiego w Poznaniu

e-mail:pekackafalkowska@ump.edu.pl

ORCID: 0000-0003-2068-7957

\section{HORTI SICCI OF JACOB BREYNE OF 1659 AND 1673}

\section{Summary}

Key words: Royal Prussia $-17^{\text {th }}$ century, history of botany, historical herbaria - the $17^{\text {th }}$ century, herbarium vivum, ethnobotany

Jacob Breyne, who lived in Gdańsk in the $17^{\text {th }}$ century, was one of the most important botanists in the Polish-Lithuanian Commonwealth. He was fascinated with the exotic flora and was also interested in the flora at home. Like many other botanists in Gdańsk in the $17^{\text {th }}$ century, he planned to publish the work devoted to autochthonous plants of Royal Prussia and Kashubia, but his plans were interrupted by his death. In the collection of Naturalis Biodiversity Centre in Leiden there are preserved two of his horti sicci prepared correspondingly in 1659 and 1673, where specimens of indigenous plants from Gdańsk Pomerania were included. They are the oldest sources of this kind to be found in the territories of early modern Poland. The author of the article presents the botanic interests of Jacob Breyne in the Pomeranian local flora. The edition of the texts from the Leiden herbaria was enclosed.

Die Horti SiCCI Des JaCOB BReyne von 1659 BIS 1673

\section{Zusammenfassung}

Schlüsselwörter: Königlichen Preußens im 17. Jahrhundert, Geschichte der Botanik, historische Herbarien im 17. Jahrhundert, herbarium vivum, Ethnobotanik

Der im 17. Jahrhundert in Danzig lebende Jacob Breyne war einer der wichtigsten Botaniker in der polnisch-litauischen Republik. Neben einer Faszination von exoti- 
scher Flora legte er ein ausgeprägtes Interesse für die heimische Flora an den Tag. Wie viele andere Danziger Botaniker im 17. Jahrhundert plante er die Publikation einer Arbeit über die heimischen Pflanzen des Königlichen Preußens und Kaschubiens, jedoch wurden seine Pläne durch den Tod durchkreuzt. In den Sammlungen des Naturalis Biodiversity Center in Leiden haben sich aber zwei seiner horti sicci erhalten, die in den Jahren 1659 und 1673 angelegt wurden und die Exemplare von einheimischen Pflanzen des Pommerellen enthalten. Dabei handelt es sich um die ältesten erhaltenen Quellen dieser Art aus dem Gebiet des heutigen Polen. Der Artikel behandelt die botanischen Interessen von Jacob Breyne für die lokale Flora in Pommern. Angefügt ist ihm eine Edition der Texte aus den Herbarien in Leiden.

\section{Bibliografia}

Adriani Spigelii Bruxellensis Philosophi Ac Medici Patavini Isagoges In Rem Herbariam Libri Duo: Cum Indice Rerum; Capitum / Adriaan van de Spiegel. - Editio prioribus correctior. Helmestadii: Heitmullerus, 1667. e-Resource: http://diglib.hab.de/ drucke/mx-171-7s/start.htm

Bauhin, Caspar. Phytopinax seu Enumeratio plantarum ab Herbariis nostro seculo descriptarum, cum earum differentiis: cui plurimarum hactenus ab iisdem non descriptarum succinctae descriptiones \& denominationes accessere: Additis aliquot hactenus non sculptarum plantarum vivis iconibus: / Casparo Bauhino Botanico \& Anatomico Acad. Basileens. ordin. Auctore. Basileae: per Sebastianum Henricpetri, 1596. e-Resource: http://docnum.u-strasbg.fr/cdm/ref/collection/coll13/ $\mathrm{id} / 45827$

Bauhin, Caspar. Pinax theatri botanici. Basileae Helvet.: Sumptibus \& typis Ludovici Regis, 1623. e-źródło: http://bibdigital.rjb.csic.es/ing/Libro.php?Libro=1442

Benkert, Davina. “The 'Hortus Siccus' as a Focal Point: Knowledge, Environment, and Image in Felix Platter's and Caspar Bauhin's Herbaria." In Sites of Mediation: Connected Histories of Places, Processes, and Objects in Europe and Beyond, 1450-1650, edited by Susanna Burghartz, Lucas Burkart and Christine Göttler, 211-239. Leiden: Brill, 2016.

Bernoulli, Johann. Johann Bernoulli's Reisen durch Brandenburg, Pommern, Preußen, Curland, Rußland und Polen in den Jahren 1777 und 1778. Leipzig: Fritsch, 1779. e-Resource: http://digital.bib-bvb.de/view/bvbmets/viewer.0.6.2.jsp?folder _id $=0 \&$ dvs $=1524388118159 \sim 461 \&$ pid $=2898229 \&$ locale $=$ pl\&usePid $1=$ true $\&$ usePid2=true

Bibliotheca Academiae Lugduno-Batavae. Catalogus deel XIV. Inventaris van de Handschriften. Eerste Afdeeling. Leiden: Leiden Universiteits-Bibliotheek, 1932.

Breyne, Jacob, Johann Philipp Breyne and Johann Friedrich Bartel. Herrn Doct. Johann Philipp Brayne nachgelassenen berühmten Naturalien Cabinets welches in Danzig in der Langgasse für baares Danziger Geld den 1765 etc. Danzig: gedruckt bey Johann Friedrich Bartels, 1765.

Breyne, Jacob. “Obs. CCLXXXIX-CCXVIII.” Miscellanea Curiosa 3 (1673): 509-518. 
Breyne, Jacob, Gedanensis. “Obs. CXXIX-CXXXIX, CXLIX-CLIII.” Miscellanea Curiosa 4 (1674): 138-146, 192-195.

Breyne, Jacob. Exoticarum aliarumque Minus Cognitarum Plantarum Centuria Prima cum Figuris Æneis Summo studio elaboratis. Gedani: Rhetius, 1678. e-Resource: urn:nbn:de:bvb:29-bv039804209-7

Breyne, Jacob. Prodromus fasciculi rariorum plantarum, Anno M.DC.LXXIX. in hortis Celeberrimis Hollandiae, praefertim Incomparabili \& Nobilissimo illo Florae Pandocheo Illustrissimi atqve Excellentissimi Domini, Domini Hieronymi van Beverningk etc. observatarum a Jacobo Breynio, Gedanensi. Cui accedunt Interrogationes de nonnullis Plantarum ab Auctore in Centuria prima descriptarum partibus, quibus, tempore editionis Centuriae primae, Idem ille ut plurimum destitutus fuit. Gedani: Rhetius, 1680. e-Resource: http://bibdigital.rjb.csic.es/ing/Libro.php?Libro=1489

Bujack, Johann Gottlieb. "Über preußische Naturforscher des 16ten, 17ten und 18ten Jahrhunderts. Bibliografischßliterärische Skizzen. Die Danziger Jacob Breyn, Johann Philipp Breyn und Jacob Theodor Klein.” Preußische Provinzial-Blätter 23 (1840): 193-209, 344-359.

Catalogi plantarum quae A. 1651 Varsaviae in hortis botanicis regis Ioannis Casimiri colebantur, secundum conspectus hortulanorum Bartholomei Gei et Jacobi Haic: accedit catalogus tertius plantarum indigenarum, quae circa Varsaviam nascuntur; Królewskie ogrody botaniczne króla Jana Kazimierza w Warszawie oraz systematyczny spis roślin tamże hodowanych. Edited by Józef Rostafiński. Kraków: Academiae Litterarum et Scientiarum Polonae apud Bibliopolam G. Gebethner et Wolff \& Drukarnia Uniwersytetu Jagiellońskiego, 1928. e-Resource: http://kpbc.umk.pl/ dlibra/docmetadata? $\mathrm{id}=49230 \&$ from $=$ pubindex $\&$ dirids $=27 \& \mathrm{lp}=111$

Clokie, Hermia Newman. An account of the herbaria of the Department of Botany in the University of Oxford. Oxford: Oxford University Press, 1964. e-Resource: https:// doi.org/10.5962/bhl.title.13736

Conwentz, Hugo Wilhelm. “'Oelhafens Elenchus' plantarum circa Dantiscum nascentium.” Schriften der Naturforschenden Gesellschaft Danzig NF 4 (1877): 1-33.

Conwentz, Hugo. "Westpreußische Botaniker der Vergangenheit." Berichte der Deutschen Botanischen Gesellschaft 29 (1911): 6-15.

Cooper, Alix. Inventing the Indigenous: Local Knowledge and Natural History in Early Modern Europe. New York: Cambridge University Press, 2007.

Dalechamps, Jacques. Historia generalis plantarum [...] [Pars prima]. Lugduni : Apud Gvlielmvm Rovillivm, 1586. e-Resource: http://bibdigital.rjb.csic.es/ing/Libro. php?Libro=4729

Doroszewska, Alina. “The oldest botanical garden in Warsaw." In Studies on the history of Botanical Gardens and Arboreta in Poland, edited by Alicja and Bogdan Zemanek, 47-58. Kraków: Instytut Botaniki im. W. Szafera PAN, 1993.

Doroszewska, Alina. "Królewskie ogrody botaniczne w Warszawie za Jana Kazimierza." Kwartalnik Historii Nauki i Techniki 31 (1986): 397-410.

Du Plessis, Enid and Mary Gunn. The Flora Capensis of Jakob and Johann Philipp Breyne. Johannesburg: Brenthurst Press, 1978.

Eichstaedt, Lorenz and Johann Möller. Exercitatio phytologica de plantis in genere. Gedani: [s.n.], 1648. e-Resource: http://digital.slub-dresden.de/werkansicht/dlf/7323/1/ 
Elenchus plantarum, circa nobile Borussorum Dantiscum, sua sponte nascentium D. Nicolai Oelhafi etc. cum synonymia earundem latina et germanica, indice autorum, locis natalibus, florum temporibus et viribus, denuo recensitus ac locupletatus a successore eius, (Laurentió Eichstadio) de quo in praefatione. Gedani: Rhete Georg Vidua et Haeredes, 1656. e-Resource: https://doi.org/10.5962/bhl.title.45250

Erndtel, Christian Heinrich. „Viridarium, Warsaviense sive Catalogus Plantarum Circa Warsaviam Crescentium." In Christian Heinrich Erndtel. Warsavia Physice Illustrata, Sive De Aere, Aquis, Locis Et Incolis Warsaviae, Eorundemque Moribus Et Morbis Tractatus; Cui Annexum Est Viridarium, Vel Catalogus Plantarum Circa Warsaviam Nascentium, 1-132. Dresdae: apud Ioh. Christoph. Zimmermanni haered. \& Ioh Nicol. Gerlachium, 1730. e-Resource: http://bcpw.bg.pw.edu.pl/dlibra/ docmetadata? $\mathrm{id}=1304 \&$ from $=$ publication

Fleischer, Alette. "Gardening Nature, Gardening Knowledge: the Parallel Activities of Stabilizing Knowledge and Gardens in the Early Modern Period." In Gardens, Knowledge and the Sciences in the Early Modern Period, edited by Hubertus Fischer, Volker R. Remmert and Joachim Wolschke-Bulmahn, 294-296. Basel: Birkhäuser - De Gruyter, 2016.

Fleischer, Alette. Rooted in fertile soil: seventeenth-century Dutch gardens and the hybrid history of material and knowledge production, proefschrift. Twente: [s.n.], 2010. e-Resource: DOI 10.3990.1.9789036530972.

Flis, Stanisław. "Maciej Ernest Borecki (Boretius) - Znany lekarz mazurski XVIII wieku." Polski Tygodnik Lekarski 38 (1956): 1637-1638.

Flis, Stanisław. "Panegiryk z pierwszej połowy XVIII wieku ku uczczeniu pamięci Macieja Ernesta Boretiusa (Boreckiego).” Komunikaty Mazursko-Warmińskie 4 (1964): 514-519.

Helwing, Georg Andreae. Supplementum florae Prussicae: seu enumeratio plantarum indigenarum post editam Floram quasimodogenitam additis synonymiis, appellationibus Latino-Germanico-Polonicis, nec non observationibus quibusdam curiosis, ultra numerum quadringentesimum aucta. Gedani: Typis Thomae Johannis Schreiberi, Senatus \& Athenaei Typographi, 1726. e-Resource: http://digital.slub -dresden.de/werkansicht/dlf/106193/1/

Helwing, Georg. M. Georgii Andreae Helwingii, pastor. Angerburg. [...] Florae campana seu pulsatilla cum suis speciebus et varietatibus methodice considerata et inter spersis variis observationibus oculis curiosorum exposita, cum XII iconibus, qvarum nonnullae nunqvam ante hac aeri incisae. [Florae campana seu pulsatilla cum suis speciebus et varietatibus methodice considerate]. Lipsiae: Tietze, 1719. e-Resource: https://polona.pl/item/m-georgii-andreae-helwingii-pastor-angerburg-florae -campana-seu-pulsatilla-cum,NzUzMDA4OTU/

Helwing, Georg. Helwingii, Georgii Andreae, cum praefatione Johannis Philippi Breynii, in qua de scriptoribus rerum naturalium Borussiae \& Poloniae agitur, \& multi errores Florae Prussicae modeste corriguntur, Flora quasimodogenita, sive enumeratio aliquot plantarum indigenarum in Prussia, quarum in herbariis hectenus editis Borussicis aut nulla, aut superficiaria facta est mentio, additis nonnullis iconibus descriptionibus et observationibus nec non annexo florilegio ad clima Prussiae accom- 
modato, in gratiam botanophilorum adornata, sp. Gedani: Imprimebat Joannes Daniel Stollius, 1712. e-Resource: http://atena.beic.it/view/action/nmets.do?DOC CHOICE $=6925666 . x m l \& d v s=1524384846621 \sim 24 \&$ locale $=$ pl\&search_terms $=\&$ show_metadata $=$ true\&adjacen $c y=\& V I E W E R \_U R L=/$ view/action $/$ nmets.do? \&DELIVERY_RULE_ID=7\&divType=\&usePid1=true\&usePid2=true

Klinggräff, Hugo von. "Zur Geschichte der Botanik in Preussen." Der neuen Preuß. Prov.-Blätter 5 (1854): 53-63.

Kurkowa, Alicja. Jakub i Jan Filip Breynowie: studium z dziejów kultury książki XVII i XVIII wieku. Wrocławm, Warszawa, Gdańsk: Zakład Narodowy im. Ossolińskich, 1989.

Loesel, Ioannes. Flora Prussica; sive, Plantae in regno Prussiae sponte nascentes. Quarum catalogum \& nomina Johannes Loeselius [...] olim disseruit, nunc additis nitidissimis iconibus rariorum partim ab aliis nondum delineatarum plerarumque Prussiae propriarum \& inquilinarum plantarum, earundemque accurata descriptione, nec non adjectis synonymiis veterum botanicorum, interspersisque observationibus historico-philologico-criticis \& medio-practicis noviter efflorescentes curante Johanne Gottsched. Regiomonti: sumptibus typographiae Georgianae, anno 1703. e-Resource: http://dfg-viewer.de/show/?tx_dlf\%5Bid\%5D=http\%3A\%2F\%2Fdigital.ub. uni-duesseldorf.de\%2Foai\%2F\%3Fverb\%3DGetRecord\%26metadataPrefix\% 3Dmets\%26identifier\%3D4722104\&tx_dlf\%5Bpage\%5D=1\&tx_dlf\%5Bdouble $\% 5 \mathrm{D}=0 \& \mathrm{cHash}=0 \mathrm{ba} 9421 \mathrm{~b} 7 \mathrm{cff} 41 \mathrm{~d} 132 \mathrm{a} 7846 \mathrm{~b} 31 \mathrm{~d} 6 \mathrm{cc} 83$

Łyskanowski, Marcin. "Polonica w czasopiśmie XVII i XVIII wieku 'Miscellanea Curiosa." Historia nauk biologicznych i medycznych 5 (1961): 55-62.

Mentzel, Christian. Centuria plantarum circa nobile Gedanum sponte nascentium adjecta appendicis loco ad Elenchum plantarum gedanensium excell. \& exper. Dn Nicolai Oelhafi, regi medici, et physici gedanensis. Dantisci: Andreæ Hünefeldij, 1650.

Mentzel, Christian. Pinax botanonymos polyglottos katholikos, Index nominum plantarum universalis, : diversis terrarum, gentiúmque linguis, quotquot ex auctoribus ad singula plantarum nomina excerpi \& juxta seriem A.B.C. collocari potuerunt, ad unum redactus, videlicet: Europaeorum Latinâ sive vetere Romanâ, Graecâ antiquâ, Italicâ cum suis, Hetruriâe, Istriae, Venetorum, Forojuliensium, nec non insularum adjacentum Malthae, Cretae vel Candiae, Lesbi, \&c. Dialectis, Hispanicâ, Lusitanicâ \& in ea regnorum Cataloniae, Valentiae, \&c. Gallicâ vetere \& neotericâ cum suis, Burgundiae, Narbonae, Parisiensium, \&ُc. idiomatibus. Anglicâ, Scoticâ \& Irlandicâ. it: Danicâ, Germanicâ cum suis, Silesiorum, Marchicorum, Pomeranorum, Borussorum \&c. sermonum proprietatibus. Belgicâ cum sua Brabanticâ. Bohemicâ, Polonicâ, Lituanicâ, Vinidicâ, Rutenicâ, Wallachicâ olim Dacicâ, Hungaricâ, Sclavonicâ, Croaticâ. \&r. Asiaticorum, Hebraeâ, Chaldaicâ, Syriacâ, Arabicâ, Turcicâ cum sua Tripolitana, \&rc. Tartaricâ, Persicâ, Malabaricâ, Bramanicâ olim Brachmanicâ, prophetarum, magorúmq[ue], veterum, Zeilanicâ sive Cingalicâ, Javanicâ, Bengalicâ, Sinicâ, Japonicâ, Malaicâ, Coreicâ. \&rc. Africanorum Aegyptiacâ, Aethiopicâ, Mauritanicâ sive Barbaricâ \& Tunensium, cum poenorum antiqua, Canaricâ \& Madagascaricâ. Americanorum, Brasilianâ, Virginianâ, Mexicanâ \& adjacentium populorum aliorúmq[ue] in insulis, \& continente solo, hinc inde habi- 
tantium, quorum sermonum nomina non omnibus, sed quibusdam tantùm plantis, quotquot apud auctores reperta fuerunt, sparsim adposita sunt. Characteribus Latinorum, Graecorum \& Germanorum maximè per Europam usitatis conscriptus, \& ita concinnatus, ut plantarum genera, species, colorum \& quarumvis partium differentiae, quotquot erudicti ad hunc usque diem adnotarunt, ordine legitimo inter se collocarenrur: citatis (quod improbum laborem requisivit) classicorum auctorum \& eorum, qui in plerisque suprâ laudatis linguis scripserunt, locis genuinis \& correctis, ab ipso Hippocrate ad nostri s: Berolini, cum gratiis \& privilegiis decennalibus S. Caes. Maj. \& Sereniss. Elect. Brandenb. [i. e. Berlin].: Sumptibus auctoris. Prostat apud Danielem Reichelium. Ex officina Rungiana, M. DC. LXXXII. [1682]. e-Resource: https://www.biodiversitylibrary.org/bibliography/86616\#/summary

Mokrzecki, Lech, ed. Gdańskie Gimnazjum Akademickie, vol. 2: Wybór źródet $z$ XVI i XVII wieku. Gdańsk: Wyd. UG, 2008.

Molhuysen, Philip Christiaan. Bronnen tot de geschiedenis der Leidsche universiteit 1574-1811, Deel 5: 1725-1765, Bronnen tot de geschiedenis der Leidsche Universiteit. Vijfde deel: 10 Febr. 1725 - 8 Febr. 1765. Gravenhage: M. Nijhoff, 1921. e-Resource: http://resources.huygens.knaw.nl/retroboeken/leidsche_universiteit/\# page $=587 \&$ accessor $=$ toc $\&$ source $=5$; https://science.naturalis.nl/en/collection/ naturalis-collections/botany/

Oelhafius, Nicolaus. Elenchus plantarum circa nobile Borusforum Dantiscum suâ sponte nascentium. : Earundem Synonyma Latina \& Germanica, loca natalitia, florum tempora \& vires exhibens. Dantisci: Typis \& impensis Georgi Rheti, 1643. e-Resource: https://fbc.pionier.net.pl/details/nnh7dRm (wyd. 1656).

Oglivie, Brian W. The Science of Describing: Natural history in Renaissance Europe. Chicago, London: University of Chicago Press, 2008.

Ooststroom, Simon Jan van. "Een 17de eeuwsch herbarium uit de omgeving van Danzig." In Gedenkboek J. Valckenier Suringar, 24 December 1864 - 17 October 1932, 208-217. Wageningen: Nederlandsche Dendrologische Vereeniging. H. Veenman \& Zonen, 1942.

Pękacka-Falkowska, Katarzyna. "Johann Philipp Breyne i jego ogrody: hortus vivus i hortus siccus." In Natura Homines. Studia z historii środowiskowej, vol. 1: Historia - klimat - przyroda. Perspektywa antropocentryczna, edited by Piotr Oliński and Wojciech Piasek, 217-228. Toruń: Wyd. UMK, 2018 [in press].

Pękacka-Falkowska, Katarzyna. "Wstęp." In Christian Heinrich Erndtel. Pamiętnik podroży uczonej do Anglii i Holandii (1706-1707). Translated and edited by Katarzyna Pękacka-Falkowska and Halina Bogusz, 9-36. Warszawa: Muzeum Pałacu Króla Jana III w Wilanowie, 2018.

Rauschert, Stephan. "Das Herbarium von Paul Herman (1646-1695) in der Forschungsbibliothek Gotha." Hercynia N.F. 7 (1970): 301-328.

Reyger, Gottfried. Soc. Phys. Ged. Secretarii. Tentamen Florae Gedanensis Methodo Sexuali Adcommodatae. Dantisci: Apud D.L. Wedel, [1764-1766]. e-Resource: https://doi.org/10.5962/bhl.title.45250

Scheuchzer, Johann Jakob. Agrostographia sive Graminum, Juncorum, Cyperorum, Cyperoidum, iisque affinium Historia. Tiguri (Zurich): Typis et Sumptibus Bodmerianis, 1719. e-Resource: http://bibdigital.rjb.csic.es/ing/Libro.php?Libro=3541 
Spalik, Krzysztof. "Pre-Linnaean herbaria viva of Helwing in the collections of the National Library of Poland and the University of Warsaw." Acta Societati Botanicorum Poloniae 83 (2014): 13-16. DOI: https://doi.org/10.5586/asbp.2014.008

Stafleu, Frans Antonie and Richard S Cowan. Taxonomic literature: a selective guide to botanical publications and collections with dates, commentaries and types, vol. 1. Utrecht: Bohn, Scheltema \& Holkema, 1976. DOI: https://doi.org/10.5962/bhl. title.48631

Sulma, Tadeusz and Zofia Schwarz. "Z dziejów botaniki na Pomorzu Gdańskim. Cz. II: Rozwój botaniki w Gdańsku w dobie Oświecenia." Studia i Materiały z Dziejów Nauki Polskiej S.B. 27 (1977): 63-118.

Sulma, Tadeusz and Zofia Schwarz. "Z dziejów botaniki na Pomorzu Gdańskim.” Studia i Materiały z Dziejów Nauki Polskiej 14 (1968): 25-74.

Szwarc, Zofia. "Prywatne ogrody botaniczne a rozwój nauk przyrodniczych w ośrodku gdańskim w XVI-XVIII w.” Kwartalnik Historii Nauki i Techniki 31 (1986): 411-444.

Szybkowska, Urszula and Magdalena Madeja-Grzyb. Herbaria i florilegia od XV do XVIII wieku ze zbiorów PAN Biblioteki Gdańskiej. Pruszcz Gdański: Wyd. Jasne, 2017.

Targosz, Karolina. Jacob Breynius 1637-1697, 'botanicus celeberrimus' w wymiarze europejskim. Kraków: Polska Akademia Umiejętności, Komisja Historii Nauki, 2010.

The Sloane herbarium: an annotated list of the Horti sicci composing it; with biographical details of the principal contributors, based on records compiled by the late James Britten. With an introd. by Spencer Savage. Rev. and edited by J. E. Dandy. London: Printed by order of the Trustees of the British Museum, 1958. e-Resource: https://archive.org/details/taxonomicliterat11976staf

Thijsee, Gerard. "Gedroogle schatten." In Bloeiende kennis: Groene ontdekkingen in de Gouden Eeuw, 49-50. Hilversum: Uitgeverij Verloren, 2012.

Vines, Sydney Howard. "Robert Morison and John Ray." In Makers of British Botany. A collection of biographies by living botanists, edited by F. W. Oliver. 8-43. Cambridge: Cambridge University Press, 1913.

Wigand, Johann. Catalogvs herbarvm in Borvssia nascentium. In Vera historia de succino Borussico, de alce Borussica, \& de herbis in Borussia nascentibus. Item, de sale creatura Dei saluberrima, consideratio methodica, \& theologica, etc., 48-88. Ienae: Typis Tobiæ Steinmanni, Anno XC. [1590]. e-Resource: http://digital.bib-bvb. de/view/bvbmets/viewer.0.6.2.jsp?folder_id=0\&dvs=1524129806321 940\& pid $=1931790 \&$ locale $=$ pl

Zasławska, Danuta Natalia. “The Floral Still Lifes of Andreas Stech.” Acta Historiae Artium Balticae 1 (2005): 101-137.

Zemanek, Alicja. "Odnalezienie prawdopodobnych śladów pierwszego polskiego zielnika królewny Anny Wazówny.” Kwartalnik Historii Nauki i Techniki 41 (1996): 197-206.

Ziarnek, Magdalena. Badacze szaty roślinnej Pomorza sprzed 1945 roku. Szczecin: Zachodniopomorski Uniwersytet Technologiczny. Zakład Botaniki i Ochrony Przyrody, Lonicera Krzysztof Ziarnek, 2012. 